\title{
PUBLIC SECTOR PAY AND CORRUPTION: MEASURING BRIBERY FROM MICRO DATA
}

\author{
Yuriy Gorodnichenko \\ University of Michigan \\ (ygorodni@umich.edu)
}

\author{
Klara Sabirianova Peter* \\ Georgia State University \\ IZA Bonn \\ (kpeter@gsu.edu)
}

November 25, 2006

\begin{abstract}
This study provides the first systematic measure of bribery using micro-level data on reported earnings, household spending and asset holdings. We use the compensating differential framework and the estimated sectoral gap in reported earnings and expenditures to identify the size of unobserved (unofficial) compensation (i.e., bribes) of public sector employees. In the case of Ukraine, we find that public sector employees receive $24-32 \%$ less wages than their private sector counterparts. The gap is particularly large at the top of the wage distribution. At the same time, workers in both sectors have essentially identical level of consumer expenditures and asset holdings that unambiguously indicate the presence of non-reported compensation in the public sector. Using the conditions of labor market equilibrium, we develop an aggregate measure of bribery and find that the lower bound estimate of the extent of bribery in Ukraine is between $460 \mathrm{mln}$ and $580 \mathrm{mln}$ U.S. dollars (0.9-1.2\% of Ukraine's GDP in 2003).
\end{abstract}

\section{Acknowledgement}

The authors would like to thank David Brown, John Earle, Bruce Kaufman, Patrick Kline, Jan Svejnar, anonymous referees, seminar participants at the University of Michigan, Georgia State University and the participants at the ACES/ASSA Meetings in Philadelphia and Boston, the IZA/World Bank conference "Employment and Development" in Berlin, and the Econometric Society European Meetings in Vienna for useful comments. Sabirianova Peter acknowledges the research support from the National Council for Eurasian and East European Research.

Keywords: corruption, bribery, public sector, wage, wage differentials, consumption, Ukraine

JEL Classification: D73, H1, J3, J4, O1, P2

* Corresponding author. Tel.: 4046513986.

E-mail addresses: ygorodni@umich.edu (Y. Gorodnichenko), kpeter@gsu.edu (K.Sabirianova) 


\section{Introduction}

Corruption undermines the strength of public institutions and hampers economic growth and development (Shleifer and Vishny 1993, Mauro 1995, Shleifer 1997, Bardhan 1997, Meon and Sekkat 2005). The cost of corruption is particularly high in developing and transition countries where bribery is endemic (EBRD 2005, Transparency International 2005). The question faced by the public and policy-makers is not whether corruption exists but its extent. Yet available estimates of bribery are imprecise, sporadic and apply to highly specific cases. Popular perception-based indices are ordinal and subjective and while informative they do not provide a reliable quantitative estimate of bribery.

In this paper we develop a novel framework to estimate the extent of bribery in the public sector using micro-level data on observable labor market outcomes, household spending, and asset holdings. Specifically, we estimate the residual wage differentials between the public and private sectors, compare these differentials with the sectoral differences in household expenditures and asset holdings, and then use the conditions of labor market equilibrium to compute a monetary value of unobserved non-taxable compensation (i.e., bribery) at the aggregate level.

We motivate our analysis by observing conflicting evidence from developed countries and several transition economies with respect to the private-public wage differentials. In a review of public sector pay in several developed countries, Gregory and Borland (1999) conclude that public sector employees generally receive higher average earnings than private sector employees.

However, a few recent studies from transition countries find the opposite result, with public sector employees receiving much lower wages than their private sector counterparts (Adamchik and Bedi (2000) in Poland, Brainerd (2002) in Russia, and Lokshin and Jovanovic (2003) in Yugoslavia).

Using recently collected data from the Ukrainian Longitudinal Monitoring Survey, we also find that public sector employees in Ukraine are significantly underpaid compared to workers in the other sectors. The wage gap between private and public firms is surprisingly large (24 to $32 \%$ conditional on worker characteristics) and remarkably stable over recent years (1997-2003). We 
examine the wage gap at different points of the conditional wage distribution and establish that average results understate the gap at the top and overstate it at the bottom of the distribution. We show that the wage gap is largest (can exceed 60\%) among the most productive and highly paid workers. Using the Machado and Mata (2005) decomposition of changes in wage distribution, we find little contribution of differences in worker characteristics to explaining the wage gap and attribute most of the wage difference to the returns to (or prices of) these characteristics. At the same time, public and private sectors exhibit very similar rates of voluntary separations, labor mobility across sectors is non-trivial, the flows in and out of the public sector are approximately the same, and the size of the public sector remains virtually unchanged over the 7 years of our data. This brings about an important question of why public sector employees on average and the most productive workers in particular continue working in the public sector despite their low rate of official pay.

We argue that bribery is the most likely explanation for the observed wage differences. In particular, we show that the wage gap remains large after correcting for endogeneity, controlling for unobservable characteristics and accounting for differences in hours of work, union participation, job security, fringe benefits, bonuses, job satisfaction, and secondary employment. More importantly, we find that the levels of consumer expenditures and asset holdings are essentially identical for workers in the public and private sectors. This finding indicates unequivocally the presence of additional non-reported monetary compensation that allows employees in the public and private sectors to enjoy similar levels of consumption. We refer to this unobserved compensation in the public sector as a bribe. We find that the gap between consumption and reported income is the largest for subsectors of public administration and health care and for occupations of public sector managers and medical workers - groups that are commonly perceived as bribe takers and have also the greatest opportunities to extract bribes.

The bribery explanation of the wage gap is consistent with a study of 31 developing countries that finds a robust negative relationship between aggregate corruption indices and relative civil-service pay at the country level (van Rijckeghem and Weder 2001). This explanation is also 
consistent with numerous media reports and surveys that portray widespread bribery in the Ukrainian public sector. For example, according to the 2002 national survey of corruption in Ukraine, $78 \%$ of the respondents believe that all or almost all government officials accept bribes, $44 \%$ indicate that they paid bribes or made gifts in one form or another at least once during the last year (Woronowycz 2003). ${ }^{1}$

The fact that bribery exists in Ukraine on a large scale is common knowledge and it has been very well documented in the literature and by the mass media. It is not something that we would like to prove or disprove in this study. What we argue here is that when bribery is widespread and exists for many years, it should appear through sectoral differences in equilibrium wages and employment flows, and we can use these differences to infer the size of bribery in the economy.

We estimate the extent of bribery at the national level by using the method of equalizing sectoral differences. There are three underlying assumptions of our method: (1) there is no bribery in the private sector, (2) there are no queues in the public sector, and (3) there is no risk of being detected taking bribes in the public sector. If any of these assumptions does not hold, we underestimate the magnitude of bribery. Using our best estimates of the residual private-public wage gap, we find that bribery accounts for at least $20 \%$ of the total wage compensation in the public sector in Ukraine, which is equivalent to $460-580$ million U.S. dollars or $0.9-1.2 \%$ of Ukraine's GDP in 2003. Our alternative estimates suggest that the amount of bribery could be as high as 750 million U.S. dollars in 2003.

The paper is organized as follows. In Section 2 we introduce our data and descriptive statistics. In Section 3 we present the estimates of the private-public wage gap on average and at different points in the wage distribution and check their robustness. In Section 4 we explore the factors that might explain the trends established in Sections 3. We present the methodology and the estimates of bribery in Ukraine in Section 5 and conclude in Section 6.

\footnotetext{
${ }^{1}$ According to the same survey, $73 \%$ of the respondents indicated they had offered money to medical workers, $25 \%$ paid traffic police, $24 \%$ paid teachers and professors, $23 \%$ claimed they had illegally compensated government communal service workers (Woronowycz 2003).
} 


\section{Data and Sample}

The data for this study are drawn from the Ukrainian Longitudinal Monitoring Survey (ULMS) which is based on a stratified, random, and nationally representative sample of 4,096 households. 8,641 individuals of age 15-72 participated in the Ukrainian survey in 2003. The response rate was $66 \%$ for households and $87 \%$ for individuals within the households. Although ULMS started only in 2003, it collected employment histories for 1986, 1991, and continuously from 1997 to 2003. In this paper we do not use the 1986 data because no respondent reports a private job for this year.

The ULMS contains rich information on household and individual characteristics such as household expenditures and asset holdings, individual earnings, hours of work, education, demographics, job tenure, union membership, quits and layoffs, parents' occupation and education, and characteristics of the primary employer such as sector, location, size, and fringe benefits. The definitions of all variables used in the empirical analysis are provided in Appendix Table A1.

The key variable in our analysis is the log of monthly contractual (accrued) wage after taxes at the primary job. We refer readers to Gorodnichenko and Sabirianova (2005) for a discussion of the advantages and shortcomings of this measure and also for the effect of a recall bias on the wage measure in the ULMS. Ideally, we would like to use an hourly wage rate to control for sectoral differences in hours of work. However, we can create such a variable only for 2003 by dividing monthly wage by monthly hours of work at the primary job (calculated as average weekly hours times 4.2). In all other years, the differences in hours are partially controlled by including a dummy variable for a full-time job.

To reduce the potential effect of mortality-related sample attrition in a retrospective survey, the sample is restricted to the prime age group $15-59 .^{2}$ Following the literature (e.g., Borjas 2002), we exclude the self-employed from the analysis of the private-public wage gap. We also leave out worker collectives (cooperatives and agricultural farms) because their wage determination process

\footnotetext{
${ }^{2}$ For the Soviet period of our data (1991) we employ sample weights that are constructed on the basis of the USSR Census 1989, with under-represented groups receiving larger weights. See Gorodnichenko and Sabirianova (2005) for further details.
} 
is different from other private firms. These criteria produce the sample of wage earners that ranges from 2,320 in 1998 to 2,893 people in 1991 (see Table 1).

We distinguish between the private sector and the two segments of the state sectorbudgetary organizations and state-owned enterprises (SOEs) and define the public sector as comprised of budgetary organizations. ${ }^{3}$ These are non-profit organizations that are financed by and fully accountable to the government, highly regulated, forced to pay according to the wage grid, and significantly influenced by the political environment. They typically provide direct services to the population, and hence employees of these organizations may receive unofficial additional payments from customers for their services. The major categories of budgetary organizations are public administration, schools, and health care institutions. ${ }^{4}$ In contrast, SOEs are mostly profit-driven institutions that are self-financed through their own activities and managed by appointed directors who are given significant freedom in decision making. They often operate in concentrated or heavily regulated industries such as natural resources, transportation, communications, the military industrial complex, and utilities. Wage payment according to the wage grid is recommended, but not strictly enforced in SOEs. Despite these differences, SOEs and public organizations are very similar in many characteristics, including hours of work, fringe benefits, union participation, labor force composition, organizational norms, morale, etc. Therefore, working in SOEs might be a better counterfactual alternative for a public sector employee than working in the private sector (see Section 5 for further discussion).

Sectoral evolution of employment from 1991 to 2003 is reported in Appendix Table A2. The share of SOE employment in our sample continuously declined from $79.6 \%$ in 1991 to $36.8 \%$ in 2003. In contrast, the private sector share increased from $1.3 \%$ in 1991 to $41.4 \%$ in 2003 . The

\footnotetext{
${ }^{3}$ The private sector is also not homogeneous and includes newly created private firms and privatized former SOEs. Although privatized firms are found to resemble SOEs in their (in)efficiency (Sabirianova, Svejnar, and Terrell 2005), they are closer to new private firms in wage setting behavior. We decided to keep a broad definition of the private sector in order to draw more general conclusions about the private-public wage gap and to compare our results to other studies.

${ }^{4}$ Several studies of the private-public wage gap use similar definitions of the public sector. For example, Mueller (1998 and 2000) includes in the public sector only those involved in public administration, health and education workers, and does not include government workers more closely related to other industries in Canada.
} 
growth of the private sector continued throughout the whole transition period - its size increased by almost 64\% from 1997 to 2002, which can be explained by large-scale privatization of state enterprises and by the entry of new private firms. In the meantime, the share of public sector employment remained relatively unchanged over the last 12 years and stayed at $19-22 \%$.

We also report the gender breakdown of the sectoral employment shares and notice that the share of public sector employment is much larger for females than for males $(31.3 \% \mathrm{vs} .10 .6 \%$ in 2003). Because of these highly significant gender differences in public sector participation, the summary statistics of the key variables are also reported by gender (see Appendix Table A3). On average, the public sector employees (both males and females) are more educated than employees in state-owned and private firms. However with respect to other characteristics (except for the firm size), the public sector and SOEs display very strong similarities. Compared to the private sector, the other two sectors have longer work experience and tenure, shorter hours of work, and higher union participation. Another important distinction between the private sector and the two state sectors are gender differences in mean characteristics. While in the private sector the gender differences in all characteristics, except for education, are not statistically significant, in both state sectors females predictably stay longer at the same enterprise, have higher union involvement, and work fewer hours.

\section{Private-Public Wage Gap}

In this section, we document the evolution of the private-public wage gap in Ukraine and present various estimates of the gap, with a special emphasis on treating the endogeneity bias due to omitted variables and self-selection.

Table 1 presents the summary statistics for the unconditional private-public wage gap in Ukraine for all workers, and separately by gender. The gap is measured as a mean difference in log of monthly wage between the sectors. Evidently, SOEs and private firms pay a noticeable wage premium relative to public organizations for both males and females. The average gap in 2003 was about $0.3 \log$ points (33-36\%). This finding is consistent with the positive private sector wage 
premium (as compared to the entire state sector) found in several other transition countries (e.g., Brainerd (2002) in Russia and Lokshin and Jovanovic (2003) in Yugoslavia), but it contrasts with the negative gap observed in developed countries. ${ }^{5}$

After controlling for the observable characteristics of workers, the conditional private-public wage gap often reduces in absolute terms but remains negative and significant for females and sometimes takes on zero or a small positive value for males (Mueller, 1998, Poterba and Rueben, 1994). Following the literature, we estimate the conditional gap from the wage equation for each year and gender:

$$
\ln w_{i t}=S_{i t} \beta+X_{i t} \gamma+\varepsilon_{i t},
$$

where $w_{i t}$ is after-tax monthly contractual wage, $S_{i t}$ is a set of indicators for working in SOEs or the private sector; $X_{i t}$ is a vector of individual characteristics such as years of schooling, a gender dummy, experience, experience squared, tenure, tenure squared, a dummy for full-time job, seven categories of firm size, and five categories of location; and $\varepsilon_{i t}$ is the error term. ${ }^{6}$ Table 2 shows the private-public wage gap ( $\hat{\beta}$ ) from equation (1) estimated for each year separately. The estimated conditional wage gap remains large in economic and statistical levels and does not show any sign of a decline from 1997 to $2003 .^{7}$

In Table 3, we provide the estimates of the wage gap for the 1997-2003 pooled sample. Private firms pay significantly higher wage than public organizations, with their conditional wage premium of $0.249 \log$ points during the 1997-2003 period (see Panel A). The SOE-public wage gap

\footnotetext{
${ }^{5}$ For example, the mean difference in log of hourly wage between the private and public sectors is estimated to be 0.086 for males and -0.236 for females in UK in 1986 (Bender, 2003); - 0.114 for both genders in Netherlands in 1986 (van Ophem, 1993); -0.225 for males and -0.336 for females in Canada in 1990 (Prescott and Wandschneider, 1999); 0.009 for males and -0.165 for females in Germany in 1984-1996 (Jurges, 2002); and - 0.060 for males and -0.200 for females in Germany in 2000 (Melly, 2005), among many other studies.

${ }^{6}$ The choice of individual covariates is quite standard. Industry dummies are not included because they are perfectly nested within the sectors. We are aware of a current debate whether it is appropriate to include the firm size variable (Gregory and Borland 1999). We include the firm size in order to control partially for the unobservable differences in non-labor compensation and job security. Without this variable, the SOE-public gap increases by 0.03 log points while the private-public gap remains unaffected. The complete earnings functions estimates for the same data are reported in Gorodnichenko and Sabirianova (2005).

${ }^{7}$ The colossal private sector wage premium in 1991 (0.482 log points or 62\%) might seem somewhat inconsistent with the rest of time-series. We note that the private sector virtually did not exist at that time $(1.3 \%$ of non-farm employment) and the premium may simply reflect a first mover advantage for very few risk takers. For that reason we exclude the 1991 data from the subsequent panel analysis and focus on the more mature transition period.
} 
is also large and highly significant ( 0.153 log points). Estimates in Panel B confirm that sectoral wage differences are not diminishing over time. It is interesting that the conditional private-public wage gap is noticeably higher for females than for males ( 0.310 vs. $0.186 \log$ points), whereas we know from previous research in developed countries that females usually enjoy a bigger wage premium in the public sector, with or without conditioning on worker characteristics (Borjas 2002, Prescott and Wandschneider 1999).

Our OLS estimates may be biased due to omitted variables and endogenous self-selection to the public sector. Among the "usual suspects" of omitted factors are individual abilities, preferences, family or neighborhood influence, etc. The most obvious solution to this problem is to add omitted variables or their proxies into a wage equation. Cross-sectional data could offer a partial treatment because of the limited number of available proxies such as test scores, parental background, number of children, place of residence, etc. Fixed effect estimates are superior in that they control for all time-invariant omitted variables that might affect both wage and sectoral choice, including unobserved abilities, sectoral preferences, accumulated family wealth, and parental influence. ${ }^{8}$

In Table 3, column OLS(2), we report the conditional private-public wage gap estimated from the wage equation that includes all covariates from OLS(1) plus marital status, number of

\footnotetext{
${ }^{8}$ Alternatively, the endogeneity bias can be addressed by using instrumental variables or switching regression models. These methods, however, require an exclusion restriction that affects strongly the choice of the sector and that is not correlated with the wage equation error term. As past extensive empirical work revealed, finding proper exclusion restrictions that satisfy both criteria is an extremely hard task. Some of the earlier used restrictions were rejected later because of their obvious correlation with $\varepsilon_{i t}$ (e.g., age, education categories, and marital status). With respect to some other variables (such as parents' occupation, parents' schooling, number of children, and household income), a debate continues whether they belong to the wage equation or to the sectoral choice equation. Children and household income could be endogenous if the after-tax wage is observed (Puhani 2000); parental education could be endogenous if it is correlated with child ability (Wooldridge 2002, p.87). Several plausible exclusion restrictions are proposed for the countries that experienced an exogenous structural shock. For example, Jovanovic and Lokshin (2004) use the industry of pre-reform employment in Russia and Falaris (2003) uses land restitution in Bulgaria. However, most of the potentially valid exclusion restrictions are time-invariant (or hardly change over time) and, therefore, these alternatives are not superior to the fixed effect specification. In addition, the existing methods correcting for selectivity bias can be very non-robust when the hazard of being selected into the public sector is collinear with the wage equation regressors (Puhani 2000). Having experimented with a number of commonly used exclusion restrictions (such as marital status, number of children, parents' occupation, household income, employment in pre-reform period, etc.), we conclude that the wage gap estimates corrected for self-selection are extremely sensitive to the choice of exclusion restrictions and thus not credible. Industry of employment in 1991 is the only restriction variable that generates the gap estimate more or less consistent with OLS and FE estimates. These estimates are reported in Appendix Table A4.
} 
children, and several variables for family background - ten categories of occupations and years of schooling of both parents. In Table 3 we also show the fixed effect (FE) estimates of the gap from equation (2): ${ }^{9}$

$$
\ln w_{i t}=S_{i t} \beta+X_{i t} \gamma+\alpha_{i}+u_{i t},
$$

where $\alpha_{i}$ are individual fixed effects.

Both OLS(2) and FE estimates indicate that the private-public wage gap is economically large, statistically significant, and not diminishing over time. The gap estimated with controls for children and family background is not statistically different from its original OLS estimate at the $5 \%$ level of significance. Furthermore, the estimated gap for males is hardly influenced by fixed effects, while the gap for females falls in FE compared to its original OLS estimate (from 0.310 to $0.204 \log$ points). This suggests that endogenous sorting into the public sector might be more important for females than for males. ${ }^{10}$

The FE estimates could be criticized for treating only the time-invariant portion of the endogeneity bias while preferences for a particular sector may change over time. To capture this possible time-varying endogeneity, we estimate an individual trend model that allows individual unobserved factors to have their own time trend:

$$
\ln w_{i t}=S_{i t} \beta+X_{i t} \gamma+\alpha_{i}+\delta_{i} t+u_{i t} .
$$

We first eliminate the constant individual effect $\alpha_{i}$ by first-differencing transformation of all variables, and then we apply the fixed effects transformation to equation (4) in order to eliminate the individual-specific trend $\delta_{i}{ }^{11}$

$$
\Delta \ln w_{i t}=\Delta S_{i t} \beta+\Delta X_{i t} \gamma+\delta_{i}+\Delta u_{i t} .
$$

\footnotetext{
${ }^{9}$ In Table 3, panel C, we also report the random effect (RE) and first-differencing (FD) estimates of the wage gap but note that the RE estimate cannot be considered as unbiased by the virtue of our assumption that $\alpha_{i}$ influence sectoral choice, i.e., $E\left(S_{i t}, \alpha_{i}\right) \neq 0$. Both RE and FD estimates of the gap are close to the OLS estimate.

${ }^{10}$ Stronger preferences of females for fewer hours of work and higher job security may partly explain why endogenous sorting into the public sector is more important for females than for males.

${ }^{11}$ The FE estimator is more efficient than the second differencing estimator under the assumption that $\Delta u_{i t}$ are serially uncorrelated.
} 
We note that such a transformation, while treating endogeneity, can generate several problems. First, it might lead to the attenuation bias due to an increased noise-to-signal ratio, especially when the number of people who switch sectors is small. This is less of a problem in our data since the number of people changing sectors is non-trivial. Among those employed in the public sector in 1997, 63\% continued working in this sector during next six years, while the remaining $37 \%$ left the sector either temporary or permanently. If we take only employees in our three sectors, about $12 \%$ of them switched sectors directly (without a break for non-employment or self-employment) at least once during the 1997-2003 period. We report the annual rates of entry to and exit from the public sector in Table 4. Second, applying FE to a first-differenced equation tends to magnify standard errors due to a smaller sample size, reduced variation in regressors, and increased variation of the error term. Despite these problems, the individual trend estimate of the private-public wage gap is large in magnitude (0.279 log points) and statistically significant (Table 3, Panel C).

In summary, all panel data estimates of the gap appear to be very close to the baseline OLS estimates and indicate that public sector employees are significantly underpaid compared to employees in SOEs and private firms, with an estimated conditional wage loss varying from 0.214 to $0.279 \log$ points relative to private sector wages and from 0.125 to $0.165 \log$ points relative to SOEs wages.

We also estimate a series of quantile regressions to examine the private-public wage gap at different percentiles of conditional wage distribution:

$$
Q_{\theta}\left(\ln w_{i t} \mid S_{i t}, X_{i t}\right)=S_{i t} \beta_{\theta}+X_{i t} \gamma_{\theta},
$$

where $Q_{\theta}$ is the $\theta^{\text {th }}$ percentile of $\ln w_{i t}$ conditional on the covariates $S$ and $X$ specified in OLS(1). ${ }^{12}$ The estimated coefficients $\beta_{\theta}$ give the conditional wage gap at the $\theta^{\text {th }}$ percentile. The distribution of these coefficients is depicted in Figure 1.

\footnotetext{
${ }^{12}$ We use the set of covariates specified in OLS(1) because including additional covariates from OLS(2) reduces the sample size significantly and the OLS(1) specification makes our estimates more comparable to other studies given that
} 
Quantile regressions produce two important results. First, public sector employees receive lower wages than private sector employees at all percentiles of the conditional wage distribution. Second, the wage gap between the private and public sectors is largest among the most productive workers.

Virtually all studies that use quantile regression methods find an upward sloping privatepublic wage gap (e.g., Hyder and Reilly (2005) for Pakistan, Melly (2005) for Germany, Mueller (1998) for Canada, Nielsen and Rosholm (2001) for Zambia, and Poterba and Rueben (1994) for United States), and according to our findings, Ukraine is no exception. It is common to find that the upper tail of the wage distribution loses the most (or gains the least) while working in the public sector. What is different in Ukraine is a non-negative intercept, meaning that all workers are being paid less when working in the public sector.

We use the Machado and Mata (2005) quantile method to decompose the measured wage gap into components due to the differences in prices of worker characteristics and the differences in observed characteristics. ${ }^{13}$ This method involves making $B$ (we chose $B=10,000$ ) independent random draws of percentiles $\theta$ from $[0,1]$ and estimating $B$ quantile regressions $Q_{\theta}\left(\ln w^{S} \mid X^{S}\right)=X^{S} \gamma_{\theta}^{S}$ for each randomly drawn percentile $\theta$ and for each sector $S=\{P R I, P U B\}$, separately. The coefficients $\left\{\beta_{i}^{P R I}\right\}_{i=1}^{B},\left\{\beta_{i}^{P U B}\right\}_{i=1}^{B}$ can be interpreted as prices for observable characteristics of workers. We also create a random sample of size $B$ from covariates $X$ for each sector and denote generated samples as $\left\{X_{i}^{P R I}\right\}_{i=1}^{B},\left\{X_{i}^{P U B}\right\}_{i=1}^{B}$. Then, we generate wage distributions $\left\{w^{K, M}\right\}_{i=1}^{B}=\left\{\beta_{i}^{M} X_{i}^{K}\right\}_{i=1}^{B}$, where $K$ and $M$ denote various combinations of sectors $\{P R I$, $P U B\}$. For example $\left\{w^{P U B, P U B}\right\}_{i=1}^{B}$ stands for actual wage distribution in the public sector;

family background and children variables are not easily available in many surveys. As discussed in Section 3, the additional covariates do not have a statistically significant effect on the estimated wage gap.

${ }^{13}$ Melly (2005) uses the same method in the analysis of the private-public wage gap in Germany. 
$\left\{w^{P R I, P U B}\right\}_{i=1}^{B}$ indicates counterfactual wage distribution for public sector employees if their observed characteristics were rewarded as in the private sector.

Using the generated sequences of slopes and observed characteristics, we compute the private sector wage premium at $k=1 \ldots 99$ percentiles of the constructed wage distributions. Figure 2 depicts four distributions of the private-public wage gap: the actual wage gap distribution $Q_{k}\left(\ln w^{P R I, P R I}\right)-Q_{k}\left(\ln w^{P U B, P U B}\right)$; a counterfactual distribution (1) that shows how much a private sector employee would gain (lose) if he/she were to move to the public sector $Q_{k}\left(\ln w^{P R I, P R I}\right)-Q_{k}\left(\ln w^{P U B, P R I}\right)$; a counterfactual distribution (2) that shows how much a public sector employee would gain (lose) if he/she were to move to the private sector $Q_{k}\left(\ln w^{P R I, P U B}\right)-Q_{k}\left(\ln w^{P U B, P U B}\right)$; and a counterfactual distribution (3) that shows the wage differences between a private sector employee and a public sector employee if the latter had betas from the private sector $Q_{k}\left(\ln w^{P R I, P R I}\right)-Q_{k}\left(\ln w^{P R I, P U B}\right)$.

The counterfactual wage gap (3) is uniformly distributed around zero at nearly all percentiles, meaning that if the characteristics of the public sector workers were rewarded as in the private sector, the wage gap would be almost zero. This suggests that sectoral differences in observable characteristics contribute little to the sectoral differences in wages. At the same time, both counterfactual wage gaps (1) and (2) are close to the actual wage gap. Thus, the magnitude and the distributional shape of the wage gap are largely determined by the differences in prices of worker characteristics.

In the following section, we explore further why the same observable characteristics are rewarded so differently in each of the three sectors.

\section{Determinants of the Private-Public Wage Gap}

To this point of our analysis, we have established three important patterns in sectoral wage differentials in Ukraine: i) the private-public wage gap is positive and economically significant; ii) 
the gap is not diminishing over time; and iii) the gap is largest among the most productive workers. This section investigates the factors that might explain these patterns.

Previous studies focused on explanations of the opposite phenomenon, that is, why a public sector employee earns a rent (i.e., positive wage premium conditional on worker characteristics). The most common answer is the specificity of the public sector, namely, its different objective function (not profit maximization) and soft budget constraints, inelastic demand for public services, difficult monitoring of public sector services, and a higher rate of unionization and hence stronger bargaining position to secure a higher wage (Mueller 2000). Most of these explanations cannot be tested with our data, except for the union effect. But if any of them were relevant for Ukraine, then the size of the private-public gap would be even bigger than the estimates reported in Section 3.

With respect to unions, previous studies generally find positive effects of union participation on wages of government employees (see Gregory and Borland (1999) for a survey of studies). Table A3 shows very high union density in the public sector and SOEs in Ukraine $(91.9 \%$ and $85.9 \%$ for females and $80.8 \%$ and $73.8 \%$ for males), which is significantly bigger than union participation in the private sector ( $46.8 \%$ for females and $47.6 \%$ for males). According to Blanchflower (1996), among 15 OECD countries only Finland and Sweden have higher union participation in the public sector. Therefore, if the union wage premium exists in Ukraine, then our gap measure would be underestimated. We test this hypothesis by including a dummy for union membership in Equation (1) for 2003 and find no statistically significant differences in wages associated with union membership. This is not surprising given the weak bargaining power of the unions inherited from the old socialist system, in which they have partnered with enterprise administration in distributing social benefits among employees. Table 5 shows that the conditional private-public wage gap hardly changes after controlling for union participation. 
Now we turn to the factors that may explain why a public sector employee earns less than an equivalent employee in the private sector, which is more pertinent to our case. In particular, we focus on wage control in an inflationary environment, differences in hours of work, non-labor compensation, job security, job satisfaction, multiple job holding, and bribery.

\subsection{Government Wage Control}

Wages in the public sector in Ukraine are paid according to a government-regulated wage grid. In an inflationary economy such as Ukraine, delayed revisions of the wage grid might result in lower wages in the public sector. It could have been an important issue during the early 1990s when Ukraine experienced a hyperinflation of three to four digits, reaching the $4735 \%$ level in 1993. After 1996, inflation was relatively mild and fluctuated from $28.2 \%$ in 2000 to $0.8 \%$ in 2002 . During the 1997-2003 period, the government implemented eight revisions of the wage grid level in the public sector, yet the gap remained large. More importantly, the fact that public employees are constantly underpaid due to delayed and imperfect adjustments in the wage grid does not explain why we do not observe higher quit rates in the public sector, as Tables 8 and 9 show.

\subsection{Hours of Work}

As we see from the descriptive statistics in Table A3, a public sector employee, on average, works fewer hours per week than a private sector employee, with a 3-hour difference for males and a 7-hour difference for females. It may not be sufficient to simply control for a full-time job as we did it in our previous estimates. It is predictable that the estimated wage gap is likely to decline if we were to use hourly wages instead of monthly wages. For 2003, we can test how sensitive our gap estimates to hourly wages are by using OLS and quantile regressions.

We report our results in Table 5 and Figure 3. To reduce the influence of outliers and a measurement error, we include only respondents who earn more than two thirds of a minimum hourly wage $(\approx 0.734 \mathrm{UAH})$. Using hourly wage rate as a dependent variable in equation (1) reduces the size of the SOE-public wage gap by only $0.036 \log$ points while the private-public gap 
falls from 0.287 to $0.193 \log$ points. As a side note, Table 5 also shows that restricting our sample to full-time employees does not make any difference for the reduction in the size of the gap. The most interesting finding from the quantile regressions (depicted on Figure 3) is that with an hourly wage rate on the left-hand side the private-SOE gap reduces significantly while the SOE-public gap remains the same at nearly all percentiles of conditional wage distribution. An important implication of this finding is that in the absence of hours of work variable the SOE-public gap can be used as an approximate measure of the private-public gap.

Despite a sizeable drop in the private-public wage gap in an hourly wage specification, the gap still remains large and positive, exceeding a 20\% level for the upper half earners. Hence there is a significant upward sloping wage gap that needs to be explained.

\subsection{Fringe Benefits and Total Labor Compensation}

It has been noted by many authors that fringe benefits may compensate lower wages (e.g., Olson 2002, Vella 1993). In Ukraine, public sector employees enjoy far more generous fringe benefits than their counterparts in the private sector (see Table 6). Compared to private firms, public organizations are more likely to provide their employees with additional medical services, free child care, vacation travel, housing subsidies, and enterprise-paid training. It is plausible to hypothesize that total labor compensation (wages plus fringe benefits) should be equalized between the sectors.

However, several facts invalidate this hypothesis. First, there are almost no differences in fringe benefits provision between the public sectors and SOEs and in some instances more workers receive benefits in SOEs than in public organizations (e.g., health coverage and transportation subsidies). Consequently, fringe benefits cannot explain the observed wage differences between the two state sectors. Second, the distribution of fringe benefits across the percentiles of conditional wage is practically flat in all sectors, as depicted in Figure 4 for the selected benefits. The flat distribution of fringe benefits does not support the upward sloping private-public gap. Even if we assume that fringe benefits account for the wage differences between SOEs and private firms, a 
significant portion of the private-public gap, particularly for the most productive workers, remains unexplained.

We also compare mean probabilities of receiving five types of bonuses across sectors using marginal effects from the probit model shown in Table $10.37 .1 \%$ of the sample report getting a bonus last year, although the exact bonus amount is unknown. In most specifications, cross-sectoral differences in probabilities of getting bonuses are not statistically significant at the $5 \%$ level, with an exception of a higher incidence of receiving a $13^{\text {th }}$ salary and performance-based bonuses in SOEs, and a higher probability of profit sharing in the private sector. Based on these findings, adding bonus amounts to wages on the LHS is likely to increase the conditional private-public wage gap (or at least not to change it).

Alternative firm-level data sources also suggest that the sectoral differences in total labor compensation might be bigger than pure wage differentials. Despite the lower percent of private sector workers receiving fringe benefits, the value of social expenditures is higher in private enterprises than in public organizations, perhaps reflecting the budgetary difficulties of financing social programs in budgetary organizations. In budgetary non-profit organizations, the average share of social benefits in total labor costs (weighted by firm employment) is $23 \%$ whereas the benefit share in state-owned enterprises is $27 \%$ and private non-farm firms is $26 \%$. ${ }^{14}$ Thus, if workers were able to assess the value of their fringe benefits and bonuses, then the estimated sectoral gap in total labor compensation would have been larger.

\subsection{Job Security and Risk Aversion}

Job security is another important factor that enters into a tradeoff with wage. Public sector employees may accept lower wages in exchange for higher job security. We can approximate individual job security by the probability of layoffs and also by the degree of wage volatility.

\footnotetext{
${ }^{14}$ Both mean differences in the share of benefits are statistically significant at the $1 \%$ level. Social benefits include expenditures on housing provision and housing subsidies of employees, cost of professional training, cost of workers' recreation and entertainment, health care payments, child care allowances and services, employer contribution to government social security schemes and private social funds, and other related expenditures. The firm-level data represent the whole population of the registered Ukrainian firms that have submitted their labor cost statistics to the State Statistics Committee in 2002 (50,400 firms with total employment of 8.5 mln workers).
} 
Table 7 and Figure 5 report a lower probability of layoffs in the public sector than in the other two sectors on average and across the wage distribution. Figure 5 also shows fewer job separations in the top deciles of the conditional wage distribution relative to the bottom deciles, which is in accordance with the upward sloping private-public wage gap. However, the differences in the probability of involuntary separations are not sufficiently large to counterbalance differences in wages. To show this, we first estimate a probit model and obtain the sectoral differences in the probability of being laid off in year $t+1$ conditional on worker characteristics in year $t$. We control for the same characteristics as in equation (1). The marginal effects reported in Table 8 indicate that a public sector employee has a lower mean annual probability of being laid off by $0.034(0.029)$ compared to a worker in the private sector (SOE) in 1997-2003. Even if there were no layoffs in the public sector, in order to eliminate the $15-20 \%$ wage gap, the probability of layoff in the private sector should be at least $0.13-0.17$, which is much greater than we observe in the data. ${ }^{15}$

Indeed, we find the large gap in expected wages, which are computed as actual wages multiplied by one minus the predicted probability of being fired. The distributions of the sectoral gap in expected monthly wage (1997-2003) and expected hourly wage (2003) are depicted in Figure 6, which is analogous to Figure 3. In Table 5, we report the OLS estimate of the gap in expected hourly wages for 2003. The OLS and quantile estimates suggest that the conditional wage gap falls slightly (by 0.015 log points on average) after controlling for the probability of being laid off.

The volatility of wages is another important dimension of job security. Table 9 contains the standard deviation of log of monthly wage and 90-10 wage differentials. Both measures indicate that wages are more compressed in the public sector than in the private sector. Public sector workers, therefore, might accept lower wage in exchange for its lower volatility. However, simple calculations show that reasonable values of worker's risk aversion cannot match the existing gap.

To parameterize the trade-off between the mean and the variance of compensation, suppose that the utility function is isoelastic and that all compensation come from wages, i.e.,

\footnotetext{
${ }^{15}$ These calculations are made by assuming risk-neutrality and equalizing expected wages in two sectors $w_{b}\left(1-\rho_{b}\right)=w_{p}(1-$ $\left.\rho_{p}\right)$, where $\rho_{b}$ and $\rho_{p}$ are the probabilities of being laid off from the public and private sectors, respectively.
} 
$U=\left(C^{1-\gamma}-1\right) /(1-\gamma)$, where $C$ is consumption and $\gamma$ is the coefficient of relative risk aversion.

Chetty (forthcoming) and Kaplow (2005) argue that the upper bound of $\gamma$ is not greater than 1.5.

Using this upper-bound estimate of risk aversion $(\gamma=1.5)$, we can compute the maximum wage gap that would compensate for the observed differences in wage dispersion between the public and private sectors. Specifically, the maximum wage gap explained by risk aversion is equal to $\frac{\gamma}{2}\left(\sigma_{P R I}^{2}-\sigma_{P U B}^{2}\right) .{ }^{16}$ By equalizing expected utility across the sectors, we obtain that the difference in wage dispersion (measured as standard deviation of the log of real wages) could reduce the privatepublic wage gap by at most 3.5 percentage points. Because SOEs and public organizations have the same degree of wage dispersion, the differences in risk aversion cannot explain the wage gap between these two sectors. Furthermore, the compensating wage differentials associated with the difference in the variation of wages practically vanish when we use the inter-temporal variation that is approximated by the standard deviation of the residuals estimated from equation (2) with individual and year fixed effects (Table 9). ${ }^{17}$

\subsection{Job Satisfaction and Multiple Job Holding}

We also check a few other factors that could potentially increase worker's utility (compensation) and hence be traded for lower wage. For instance, it might be that public sector employees accept lower wages because of higher moral satisfaction they derive from their job. However, employees in the public and private sectors are ceteris paribus equally satisfied with their jobs, and together they are less satisfied than workers in SOEs (see Table 10).

Finally, we do not find any evidence that public sector employees have a higher probability of deriving additional income from secondary activities. Table 10 demonstrates no statistically significant differences in secondary employment across all sectors. The share of multiple job

\footnotetext{
${ }^{16}$ Given that the distribution of wages is approximately log-normal, the expected utility in sector $x$ is $E(U)=E(\exp \{(1-\gamma) \ln C\}-1) /(1-\gamma)=\left(\exp \left\{(1-\gamma) \mu_{x}+\frac{1}{2}(1-\gamma)^{2} \sigma_{x}^{2}\right\}-1\right) /(1-\gamma)$, where $\mu_{x}$ is the mean of log wages and $\sigma_{x}$ is the standard deviation of log wages.

${ }^{17}$ Following Hubbard, Skinner and Zeldes (1995), Blundell and Preston (1998), Meghir and Pistaferri (2004) and others, we use error dispersion in the wage equation to measure income uncertainty and volatility.
} 
holders is so small $(2.3 \%$ in 2003$)$ that adding together wages from primary and secondary jobs has hardly any effect on the estimated sectoral wage gap.

\subsection{Expenditures and Assets}

Our analysis makes evident that cross-sectoral differences in fringe benefits, layoffs, wage volatility, job satisfaction, bonuses, and secondary employment explain only a small portion of the observed wage gap, and a significant part of the wage gap must be determined by other forces. One can always argue that we ignore other unobservable job amenities that could possibly explain why public sector workers accept lower wages in exchange for these amenities (e.g., lower efforts, prestige, social status, etc.). However in this case, as with any non-pecuniary job benefits, lower wage must translate into lower consumption expenditures. In other words, the sectoral gap in consumer spending should be approximately equal to the gap in reported earnings unless public sector employees have unobservable, non-reported earnings. We investigate below if this implication holds in our data.

Because information on expenditures and assets is available at the household level, we aggregate our individual variables in equation (1) to the household level and estimate the following base wage equation for the 2003 household data:

$$
\ln w_{h}=\beta_{0}+\beta_{1} N_{h}^{S O E}+\beta_{2} N_{h}^{P R I}+\beta_{3} N_{h}^{O T H}+\beta_{4} N_{h}^{E A R}+\bar{X}_{h} \gamma+\bar{\varepsilon}_{h},
$$

where bars indicate that independent variables and errors are averaged across all wage earners in household $h ; X_{h}$ include the same vector of covariates as in equation (1) aggregated at the household level (i.e., years of schooling, gender, experience, experience squared, tenure, tenure squared, full-time job, firm size, and location); $N_{h}^{S O E}, N_{h}^{P R I}, N_{h}^{O T H}$ denote the number of household members employed in SOEs, private firms, and other sectors (collectives), respectively; ${ }^{18}$ and $N_{h}^{E A R}$

\footnotetext{
${ }^{18}$ Coefficients are easier to interpret when we use the number of the employed household members instead of the employment shares. For example, $\beta_{1}$ shows a marginal increase in household earnings if a household member is employed in SOEs instead of being employed in a public organization. To have a complete account for household earnings, we included workers in other sectors (collectives) in this part of the analysis.
} 
is the number of household wage earners. Households with no wage earners are excluded from the analysis.

We employ three definitions of labor compensation $\left(w_{h}\right)$ : household total of individual monthly contractual (accrued) wages at the primary job; total wages received last month by all household members at their primary jobs; and total earnings in the form of money, goods, and services received last month by all household members from their primary and secondary jobs. All wages and earnings are net of taxes. As shown in Table 11, all three estimated household wage functions are consistent with our previous findings and indicate a significant wage gap between the public and non-public sectors. A marginal increase in total household earnings when a member is employed in the private sector instead of being employed in the public sector is $0.163-0.175(0.102-$ 0.124 for SOEs) log points, ceteris paribus. Sectoral differences in earnings are statistically significant at the $1 \%$ level.

To make estimates in household income and consumption functions comparable, we need to make one more step in aggregation of income measure, that is, we need to add the non-labor portion of household income. This will also require using finer controls for the household composition, including the number of major contributors to non-labor income.

$$
\ln Y_{h}=\beta_{0}+\beta_{1} N_{h}^{S O E}+\beta_{2} N_{h}^{P R I}+\beta_{3} N_{h}^{O T H}+\beta_{4} N_{h}^{E A R}+\beta_{5} N_{h}^{H H M}+\bar{X}_{h} \gamma+\bar{\varepsilon}_{h},
$$

where $Y_{h}$ is total household income comprised of contractual monthly labor earnings from all jobs, accrued monthly pensions, and other types of income actually received last month (stipends, social payments, alimonies, income from capital investment, rental income, etc.); $N_{h}^{H H M}$ is the vector of household composition variables such as the number of household members, the number of pensioners (the largest source of non-labor income), and the number of children 15 years and younger. After adding non-labor income, the income premium associated with household member working in the private sector and SOEs remains large and statistically significant at the $1 \%$ level (0.135 and 0.104, respectively, as shown in Table 11). 
Now we can replace the dependent variable in equation (7) with the measures of household expenditures and examine if there is a consumption gap across sectors in the following model:

$$
\ln C_{h}=\beta_{0}+\beta_{1} N_{h}^{S O E}+\beta_{2} N_{h}^{P R I}+\beta_{3} N_{h}^{O T H}+\beta_{4} N_{h}^{E A R}+\beta_{5} N_{h}^{H H M}+\bar{X}_{h} \gamma+\bar{\varepsilon}_{h},
$$

where $C_{h}$ is a measure of consumption expenditures. Table 12 provides the consumption gap estimates for durables and nondurables, and Table A5 shows separate estimates for the different subsets of consumer nondurables such as food (food, beverages, and tobacco), apparel, services (transportation, health care, education, entertainment, and recreation), and non-durables less food. ${ }^{19}$ Regardless of the measure, we do not find significant differences in expenditures of workers across sectors. ${ }^{20}$ At the same time the coefficients on other covariates are generally consistent with standard theoretical predictions. For example, Table 12 and A5 show that schooling has positive and statistically significant returns in almost all household income and expenditure functions (except for durables).

In principle, workers with different level of true earnings could have comparable levels of expenditures if, for example, private sector employees save more (consume less) because of their job and wage uncertainty. Note that we focus on contractual wages rather than actual wages because contractual wages are less affected by transitory income shocks and thus can serve as a proxy for permanent income. We have also shown that the sectoral differences in job uncertainty and wage volatility are so small (see Section 4.4) that they are unlikely to induce savings in the private sector sufficient to equalize expenditures. Indeed, we find that households with workers in the private sector do not hold more assets (accumulated savings) than households with public sector workers. $^{21}$ Tables 11 and A5 report that employees in the private and public sectors have an

\footnotetext{
${ }^{19}$ The questionnaire contains information on separate expenditure items: food, alcoholic and non-alcoholic beverages, and tobacco purchased in the last 7 days and expenses on clothing and apparel, transport services, health care services, education, entertainment, and recreation during the last month. These expenditure items are aggregated into monthly expenditures on non-durables (all weekly expenses are multiplied by 4 ).

${ }^{20}$ We did not detect any principal differences in spending patterns by examining the composition of household expenditures across different sectors. To reduce the potential effect of extreme spending (e.g. large impulse purchase last month) on the estimates, we use the Huber robust regression method.

${ }^{21}$ We also find that public sector workers are no more likely to have debts for utility payments than employees in other sectors. These utility debts are one of the largest sources of credit to individuals since the consumer credit market is not developed in Ukraine.
} 
essentially identical probability of possessing cars, phones, cell phones, and computers, and they live in better housing conditions (with higher market value and larger total living space) than households with SOEs workers. Hence the precautionary motives of workers cannot reconcile the sizeable sectoral gap in wages with the minor gap in expenditures and assets. $^{22}$

The same set of controls in both the income equation (7) and the consumption equation (8) allows us to subtract one equation from another and estimate the consumption-income gap directly as follows:

$$
\ln C_{h}-\ln Y_{h}=\beta_{0}+\beta_{1} N_{h}^{S O E}+\beta_{2} N_{h}^{P R I}+\beta_{3} N_{h}^{O T H}+\beta_{4} N_{h}^{E A R}+\beta_{5} N_{h}^{H H M}+\bar{X}_{h} \gamma+\bar{\varepsilon}_{h},
$$

where $C_{h}$ is monthly expenditures on non-durables, $Y_{h}$ is total household income, $\ln C_{h}-\ln Y_{h}$ is the consumption-income gap (or "C-Y gap"), and all other variables are defined as above. ${ }^{23}$ An important property of this specification is that it controls for any unobservable household characteristics that are omitted and simultaneously affect household income and consumption. Most likely the estimates of equation (9) understate the extent of the consumption-income gap in the public sector because workers in SOEs and the private sector are likely to receive unofficial nontaxable compensation ("payments in envelopes") (World Bank 2006). ${ }^{24}$ In line with the estimates of income and consumption functions, we find that the consumption income gap in the public sector

\footnotetext{
${ }^{22}$ It is possible that the coefficient on private ownership might be biased downwards in the asset (and perhaps consumption) functions if members of wealthy families are more likely to get a job in the public sector (so called the "elite hypothesis"). The employment flow analysis (entry, exit, and tenure) indicates that employees in the public sector are no more attached to their jobs than in two other sectors, and thus it is unlikely the elite would have special preferences towards typical jobs in the Ukrainian public sector. After including several measures of previously accumulated family wealth (such as aggregate earnings of all members of the current household in 1991 under central planning and lagged total earnings of other household members) and parental occupations into consumption and asset functions (8), we did not find changes in the signs and the magnitude of the reported sectoral coefficients (Table A8). We believe that bribery in Ukraine is more likely to occur on the job rather than in obtaining a job. However, it may not be the case in other developing countries with higher total (official and unofficial) compensation in the public sector, where bribery and family connections might be necessary in overcoming high entry barriers to obtain more attractive public sector jobs (e.g. Cameroon, Haiti, India, Indonesia, etc.). In these countries it is very important to look carefully at the factors of entry and exit (including parental background and family wealth), which, if ignored, might bias results in cross-sectional earnings and consumption/asset functions.

${ }^{23}$ Alternatively we estimated equations (6) through (9) with controls that characterize the household head (defined as the person with largest earnings). The results are reported in Appendix tables A6 and A7. They are very similar to the specifications that use controls averaged for household wage earners.

${ }^{24}$ Estimates from equation (9) can overstate the consumption-income gap if public sector employees 1) systematically save less, 2) systematically spend less on durables, or 3) have greater complementarity in consumption and leisure than workers in other sectors. These cases, however, contradict to the equality of asset holdings (wealth) and consumption of non-durables across sectors that we found previously.
} 
is economically and statistically significant, and it is $7.2-7.3 \%$ greater than in the two other sectors (Table 11).

\subsection{Bribery}

Our findings clearly suggest that the sectoral differences in expenditures and asset holdings are considerably smaller than the sectoral differences in wages. Thus, we cannot attribute the large private-public wage gap in Ukraine to the differences in non-pecuniary job amenities such as job security, fringe benefits, job satisfaction, efforts, etc. The similar levels of consumer expenditures across sectors unambiguously indicate that public sector employees receive unobserved monetary compensation that allows them to enjoy the level of consumption comparable to the consumption of workers in the other sectors. We refer to this unobserved, non-reported compensation as a bribe.

By its nature, bribery is unobserved (or at least unreported by bribe receivers) and, hence, the hypothesis that bribes explains the wage gap cannot be tested directly. However, we can test the bribery hypothesis indirectly by examining the variation of the consumption-income gap across occupations and subsectors of the public sector. It has been found by Mocan 2004, Hunt 2005, and others that certain occupations and subsectors of the public sector are more prone to corruption than others. For example, $73 \%$ of the respondents in the recent survey of corruption in Ukraine indicated they had offered money to medical workers (Woronowycz 2003). Likewise, the incidence of corruption appears to be very high in enforcement agencies and public administration.

Earlier we have shown that the wage gap is the largest among the highly paid workers who may extort larger side payments because of either their high positions within the government hierarchy or ability to provide better services (e.g., high-quality physicians). Now we can extend this analysis further by allowing the consumption-income gap in equation (9) to vary across major occupational groups and subsectors (such as public administration, education, health care and social work, and other industries which include army and public organizations in arts, culture, and 
science) ${ }^{25}$ If the bribery hypothesis holds, then the groups that commonly perceived as bribe takers should display larger positive discrepancy between consumption and income. To avoid the plethora of dummy variables for each household member (interacted with occupations and subsectors), we use characteristics of the head of the household in equation (9). ${ }^{26}$ The results are reported in Table 12 , with the private sector as an omitted category.

Consistent with the predictions of the bribery hypothesis, we find that the largest consumption-income gap is observed in public administration (including police, customs, and tax authorities) and health care (which also includes social work). The consumption-income gap is 0.238 and $0.247 \log$ points respectively larger when compared to the gap in the private sector. Table 12 also provides two specifications with occupations: column (3) compares typical occupations in the public sector with all occupations in the private sector assuming skill transferability (public sector workers might choose a different occupation when they move to the private sector); and column (4) compares occupations in the public sector with the same occupations in the private sector assuming skill non-transferability. In both cases we see the gap is larger for public sector managers ( 0.247 log points) and health care professionals and associate professionals $(0.226 \log$ points). These occupations and subsectors provide services that have highly inelastic demand and, thus, create the greatest opportunities to extract bribes.

In addition to these formal tests, the bribery hypothesis is consistent with many other pieces of evidence. Indeed, numerous media reports and surveys indicate widespread bribery in the Ukrainian public sector (e.g., Woronowycz 2003, Cabelkova and Hanousek 2004). Ukraine is persistently at the bottom of the world distribution of the Transparency International Corruption Perceptions Index. Ukraine was ranked 69-70 among 85 surveyed countries in 1998, 87-88 among 90 countries in 2000, and 122 among 146 countries in 2004 (Transparency International 2005). ${ }^{27}$

\footnotetext{
${ }^{25}$ Further breakdown of the public sector cannot be done with these data because finer disaggregation leads to having a few observations per cell.

${ }^{26}$ We thank a referee for suggesting this specification. The results are similar if we control with average household characteristics.

${ }^{27}$ In addition to individual consumers, bribes are frequently paid by corporate customers of public sector services. The EBRD/World Bank enterprise survey shows that $27.5 \%$ of firm managers in 2004 (34.9\% in 2002) reported that they
} 
Pervasive and persistent bribery in Ukraine is consistent with the positive and time-invariant private-public wage gap.

\section{Measuring Bribery}

In this section, we use the equalizing differences framework to obtain an estimate of bribery at the country level. In a labor market with unconstrained entry and exit, equilibrium is achieved when the total worker compensation is equalized across sectors. ${ }^{28}$ In this framework bribery, as with any other form of non-labor compensation, is going to be reflected in compensating wage differentials across sectors. There are three underlying assumptions to this method: there is no bribery in the private sector, there are no queues in the public sector, and there is no risk of being detected taking bribes. If private sector employees receive bribes (e.g. for utility repairs, phone installation, etc.), then our estimate of aggregate bribery is going to be understated. If there are entry constraints in the public sector (in the form of queues or bribes to get a job in the public sector), then our bribery measure is also going to be understated because any additional investment in acquiring a job in the public sector will result in higher reservation wage, longer job tenure, and fewer quits in the public sector. ${ }^{29}$ We find that voluntary turnover in the public sector is no less than in the other sectors, and tenure in public organizations is no longer than in SOEs (Tables 8, 9, and A3). Thus, entry constraints do not appear to be important in Ukraine. If there is a significant risk of being detected (which is likely to be low in a country where bribe is a social and acceptable norm), then workers in the public sector should demand higher bribes to compensate for the risk.

\footnotetext{
have to pay some irregular payments/gifts for activities related to customs, taxes, licenses, regulations or services frequently, usually or always (compared with 9.9\% in Czech Republic and Hungary, 4.7\% in Slovenia, 8.2\% in Germany and South Korea but 52.9\% in Kyrgyz Republic and 39.3\% in Russia) (World Bank 2006).

${ }^{28}$ Even if the employer sets the wage (which is a quite plausible assumption given that trade unions are very weak in Ukraine), it is the workers who move across sectors and eliminate arbitrage opportunities. If the private sector employees persistently receive larger rents (due to "efficiency wage" policies), then we would observe lower exit rates and longer tenure in the private sector, which we do not see in our data. The similar rates of voluntary separations in the private and public sectors contradict to the efficiency wage argument and may be also taken as evidence that arbitrage opportunities are eliminated in the labor market. Hence, our no-arbitrage argument does not depend on whether labor markets are competitive.

${ }^{29}$ Several studies indicate higher wages in the public sector in countries with relatively high corruption (Terrell 1993 for Haiti and Nielsen and Rosholm 2001 for Zambia). In these countries bribery is likely to appear on the quantity side in the form of queues or side payments to get a job in the public sector.
} 
In our calculations we ignore general equilibrium effects, which, however, are likely to amplify the magnitude of bribery. Since in equilibrium after-tax compensation in the public and private sectors is equalized, it must hold, ceteris paribus, that

$$
W_{p}=W_{b}(1+\beta),
$$

where $W_{b}$ is average annual after-tax earnings in the public sector, $W_{p}$ is annual after-tax earnings in the private sector, and $\beta$ is the proportion of annual earnings received in the form of bribes by the average worker in the public sector. Because current wage is the best predictor of future wages and of the net present value of wage stream, this condition also applies to life-time earnings.

Thus, the total amount of bribes in the public sector $(\boldsymbol{B})$ is equal to $N_{b} W_{b} \beta$, where $N_{b}$ is the number of employees in the public sector. The corresponding formula for the amount of bribes using the hourly wage rate is $N_{b} w_{b} h_{b} \beta$, where $w_{b}$ is the average after-tax hourly wage in the public sector and $h_{b}$ is annual hours of work in the public sector.

In these calculations it is assumed that the wage gap $\beta$ is the same for all workers. However, our quantile estimates suggest that the wage gap is increasing with the level of conditional wage. We can account for this fact by weighting the estimated wage gap in each percentile $\left(\beta_{\theta}\right)$ by the corresponding level of wage $\left(w_{b \theta}\right)$ :

$$
\boldsymbol{B}=N_{b} h_{b} \frac{1}{100} \sum_{\theta=1}^{100} w_{b \theta} \beta_{\theta},
$$

where $\theta$ is the $\theta^{\text {th }}$ percentile of the wage distribution.

Since $\beta$ is not observed, we use the estimate of $\hat{\beta}$ from equations (1)-(5) to compute the proportion of annual earnings received in bribes as $(\exp (\hat{\beta})-1)$. Table 13 shows the aggregate measures of bribery in the public sector in 2003 for several alternative estimates of $\beta .^{30}$

\footnotetext{
${ }^{30}$ To compute the amount of bribes, we use the following data for 2003: GDP $=264,165$ million $\mathrm{UAH} ; N_{b}=3,741$ million people, average before-tax monthly wage of the public sector employee $=351 \mathrm{UAH}$; total wage bill $=64,966$ mln UAH; effective income tax rate (to compute after-tax monthly wage) $=20.8 \%$ (State Statistics Committee of Ukraine 2003).
} 
The range of the estimated amount of bribes in the public sector is rather large - from 1,662 mln UAH to 4,434 mln UAH. As previous analysis indicated, some estimates are better than others. Conditional wage gap estimates are superior to unconditional ones for the obvious reason of accounting for the differences in worker characteristics. We are indifferent between the various panel data estimates because they are close to each other and distributed compactly around the pooled OLS estimate. We prefer hourly wage over monthly wage since it allows us to control for the sectoral difference in hours of work. We would choose expected hourly wage over actual hourly wage in order to account for the difference in job security. The quantile estimates are superior to the OLS estimates in computing bribery because they give more weights to high earners who are likely to extract larger bribes. We use both SOE-public and private-public gap measures to define the range of our preferred bribery estimates. ${ }^{31}$

Based on our preferred wage gap estimates, the amount of bribery in the public sector in Ukraine equals 2,438-3,094 mln UAH (457-580 mln U.S. dollars), which translates into 0.9-1.2\% of GDP and 3.8-4.8\% of the total wage bill in the economy. This estimate is likely to be a lower bound because of potential bribery in the private sector, soft budget constraints in the public sector, non-profit objective function of public organizations, larger bonuses in SOEs and private firms, etc. Even though this lower bound estimate is large, we believe it is entirely plausible. According to various estimates, the size of the shadow (unofficial) economy in Ukraine is at least $30 \%$ of GDP (Johnson et al 2000, Schneider and Enste 2000, Alexeev and Pyle 2003). Suppose that the public sector employees extract bribes by allowing the activity of the shadow economy, then the effective tax rate on the shadow economy would be about $4 \%(=1.2 \%$ GDP in bribes divided by the size of the shadow economy (30\% of GDP)). In contrast, the tax burden on the official sector is much higher (the value added tax alone is $20 \%$ ) and, thus, bribery can be a profitable mechanism of tax evasion.

\footnotetext{
${ }^{31}$ SOEs and public organizations share a lot of similarities in terms of the variance of wages, hours of work, fringe benefits, union participation, and many other characteristics; and, for that reason, public employees might consider working in SOEs as a better alternative than working in the private sector.
} 


\section{Conclusions}

Our analysis provides the first systematic measure of bribery using micro-level data on observable labor market outcomes, household spending, and asset holdings. Bribery is a social scourge in developing and transition countries. However, available estimates of bribery are qualitative and subjective. We show how one can obtain a simple and robust estimate of bribery from income, expenditures and asset holdings data. Specifically, we use the compensating differential framework and the estimated sectoral gap in expenditures and reported earnings to identify the size of unobserved (unofficial) compensation (i.e., bribes) of public sector employees. Using the conditions of labor market equilibrium, we offer a technique to calculate an aggregate measure of bribery in a country or a sector. Since we make only a few assumptions, our method should be practically helpful in welfare calculations and designing anti-corruption policies throughout the world.

In the case of Ukraine, we find that public sector employees receive on average $24-32 \%$ less in monthly wages than their private sector counterparts and that the size of the wage gap does not diminish over time. The gap remains large after controlling for a number of covariates and timeinvariant unobservable worker characteristics. We also find that the private-public wage gap is positive at all percentiles of the conditional wage distribution, and it increases with worker productivity, reaching $67.5 \%$ in the $90^{\text {th }}$ percentile of the wage distribution. All of these empirical observations are consistent with pervasive bribery in Ukraine.

We attribute the significant portion of the observed differences in reported earnings to bribes (20-27\% of public sector wages). Our analysis of household expenditures and asset holdings allows us to conclusively rule out theories that lower wages of public worker employees are offset by nonpecuniary characteristics of a public sector job such as efforts, fringe benefits, job satisfaction, job security, etc. We strengthen our analysis by examining a better counterfactual (SOEs) for the public sector. We find that large sectoral differences in wages are not translated into comparable differences in the levels of consumer expenditures and wealth as employees in the public and 
private sectors enjoy similar levels of consumption. We show that corruption prone occupations and subsectors of the public sector have the largest discrepancy between consumption and income, thus supporting our explanation of the wage gap being driven by bribes.

Using a no-arbitrage argument, we develop an aggregate measure of bribery and find that the lower bound estimate of the extent of bribery in Ukraine is between 460 million and 580 million U.S. dollars, which is equivalent to $0.9-1.2 \%$ of Ukraine's GDP and $3.8-4.8 \%$ of the official wage bill in 2003. Hence, at least $1 \%$ of GDP should be allocated to ensuring fair wages in the public sector. Given that the wage gap is particularly large at the top of the wage distribution, the decompression of wages in the public sector might be a necessary prescription for reducing corruption at the top levels. Although ensuring fair wages in the public sector is necessary in reducing corruption, it is not a sufficient condition and should be complemented with other measures such as increasing transparency and competition in the public sector, improving accountability and enforcement, etc. that reduce the incentives and powers to extract bribes.

We believe that combining expenditures/asset and income data is a fruitful avenue in the analysis of the private-public wage differentials. Since household budget surveys are available for many countries, our analysis can be easily replicated in other transition and developing countries where bribery is present.

\section{References}

Adamchik, Vera A., Bedi, Arjun S., 2000. Wage differentials between the public and the private sectors: Evidence from an economy in transition. Labour Economics 7, 203-224.

Alexeev, Michael, Pyle, William, 2003. A note on measuring the unofficial economy in the former Soviet Republics. Economics of Transition 11(1), 153-171.

Bardhan, Pranab, 1997. Corruption and development: a review of issues. Journal of Economic Literature 35(3), 1320-1346.

Bender, Keith A., 2003. Examining equality between public and private sector wage distributions. Economic Inquiry 41, 62-79. 
Blanchflower, David, 1996. The role and influence of trade unions in the OECD. Discussion paper,

No. 310. Center for Economic Performance, London School of Economics.

Blundell, Richard, and Ian Preston, 1998. Consumption inequality and income uncertainty. Quarterly Journal of Economics 113(2), 603-640.

Borjas, George J., 2002. The wage structure and the sorting of workers into the public sector. NBER Working paper No. 9313.

Brainerd, Elizabeth, 2002. Five years after: The impact of mass privatization on wages in Russia, 1993-1998. Journal of Comparative Economics 30, 160-190.

Cabelkova, Inna, Hanousek, Jan, 2004. The power of negative thinking: corruption perception and willingness to bribe in Ukraine. Applied Economics 36(4), 383-397.

Chetty, Raj, forthcoming. A bound on risk aversion using labor supply elasticities, forthcoming in American Economic Review.

European Bank for Reconstruction and Development (EBRD), 2005. Transition report 2005. London: EBRD.

Gorodnichenko, Yuriy, Sabirianova, Klara, 2005. Returns to schooling in Russia and Ukraine: a semiparametric approach to cross-country comparative analysis. Journal of Comparative Economics 33(6), 324-350.

Gregory, Robert, Borland, Jeff, 1999. "Recent developments in public sector labor markets," in O. Ashenfelter and D. Card, eds., Handbook of Labor Economics 3C, Amsterdam: Elsevier Science, North-Holland, 3573-3630.

Hubbard, R. Glenn, Jonathan Skinner, Stephen P. Zeldes, 1995. Precautionary saving and social insurance. Journal of Political Economy 103(2), 360-399.

Hunt, Jennifer, 2005. Why are some public officials more corrupt than others? NBER Working Paper, No. 11595.

Hyder, Asma, Reilly, Barry, 2005. The public sector pay gap in Pakistan: a quantile regression analysis. PRUS Working Paper, No. 33.

Johnson, Simon, Kaufman, Daniel, McMillan, John and Woodruff, Christopher, 2000. Why do firms hide? Bribes and unofficial economy after communism. Journal of Public Economics $76,495-520$.

Jurges, Hendrik, 2002. The distribution of the German public-private wage gap. Labour 16(2), 347 381. 
Kaplow, Louis, 2005. The value of a statistical life and the coefficient of relative risk aversion. Journal of Risk and Uncertainty 31(1): 23-34.

Lokshin, Michael M., Jovanovic, Branko, 2003. Wage differentials and state private sector employment choice in Yugoslavia. Economics of Transition 11 463-491.

Machado, Jose A., Mata, Jose, 2005. Counterfactual decomposition of changes in wage distributions using quantile regression. Journal of Applied Econometrics 20, 445-465.

Mauro, Paolo, 1995. Corruption and growth. Quarterly Journal of Economics 110(3), 681-712.

Meghir, Costar, and Luigi Pistaferri, 2004. Income variance dynamics and heterogeneity. Econometrica 72(1), 1-32.

Melly, Blaise, 2005. Public-private sector wage differentials in Germany: Evidence from quantile regression. Empirical Economics 30, 505 - 520.

Meon, Pierre-Guillaume, Sekkat, Khalid, 2005. Does corruption grease or sand the wheels of growth? Public Choice 122, 69-97.

Mocan, Naci, 2004. What determines corruption? International evidence from micro data. NBER Working Paper, No. 10460.

Mueller, Richard E., 1998. Public-private sector wage differentials in Canada: Evidence from quantile regressions. Economics Letters 60, 229-235.

Mueller, Richard E., 2000. Public and private-sector wage differentials in Canada revisited. Industrial Relations 39, 375-400.

Nielsen, Helena S., Rosholm, Michael, 2001. The public-private sector wage gap in Zambia in the 1990s: A quantile regression approach. Empirical Economics 26, 169-182.

Olson, Craig A., 2002. Do workers accept lower wages in exchange for health benefits? Journal of Labor Economics 20, 91-114.

Poterba, James M., Rueben, Kim S., 1994. The distribution of public sector wage premia: new evidence using quantile regression methods. NBER Working paper, No. 4734.

Prescott, David, Wandschneider, Bo, 1999. Public-private sector wage differentials in Canada: Evidence from 1991 and 1982 surveys of consumer finance. Applied Economics 31, 723 731.

Puhani, Patrick A., 2000. The Heckman correction for sample selection and its critique. Journal of Economic Surveys 14, 53-68. 
Sabirianova, Klara, Svejnar, Jan, Terrell, Katherine, 2005. Foreign investment, corporate ownership, and development: are firms in emerging markets catching up to the world standard? IZA Discussion Paper, No. 1457. IZA, Bonn.

Schneider, Friedrich, Enste, Dominik H., 2000. Shadow economies: size, causes and consequences. Journal of Economic Literature 38(1), 77-114.

Shleifer, Andrei, 1997. Government in transition. European Economic Review 41, 385-410.

Shleifer, Andrei, Vishny, Robert, 1993. Corruption. Quarterly Journal of Economics 108(3), 599617.

State Statistics Committee of Ukraine, 2003. Yearbook of Ukraine, Kyiv: State Statistics Committee.

Terrell, Katherine, 1993. "Public-private wage differentials in Haiti: Do public servants earn a rent?” Journal of Development Economics 42, 293-314.

Transparency International, 2005. Annual Report 2004.

van Ophem, Hans, 1993. A modified switching regression model for earnings differentials between the public and private sectors in the Netherlands. Review of Economics and Statistics 75, 215-224.

van Rijckeghem, Caroline, Weder, Beatrice, 2001. Bureaucratic corruption and the rate of temptation: do wages in the civil service affect corruption, and by how much? Journal of Development Economics 65, 307-331.

Vella, Francis, 1993. Nonwage benefits in a simultaneous model of wage and hours: Labor supply functions of young females. Journal of Labor Economics 11, 704-723.

Wooldridge, Jeffrey, 2002. Econometric analysis of cross section and panel data. Boston, MA: MIT Press.

World Bank, 2006. Business Environment \& Enterprise Performance Surveys (BEEPS), available at http://www.worldbank.org/.

Woronowycz, Roman, 2003. Nationwide survey reveals culture of corruption in Ukraine. The Ukrainian Weekly 4(71), January 26. 
Table 1: Unadjusted Private-Public Wage Gap by Gender and Year, Log Difference

\begin{tabular}{|c|c|c|c|c|c|c|c|c|}
\hline & 1991 & 1997 & 1998 & 1999 & 2000 & 2001 & 2002 & 2003 \\
\hline \multicolumn{9}{|c|}{ All workers } \\
\hline \multirow[t]{2}{*}{ SOE } & $0.201 * * *$ & $0.181 * * *$ & $0.207 * * *$ & $0.215^{* * *}$ & $0.236 * * *$ & $0.262 * * *$ & $0.270 * * *$ & $0.286^{* * *}$ \\
\hline & $(0.024)$ & $(0.031)$ & $(0.030)$ & $(0.029)$ & $(0.030)$ & $(0.029)$ & $(0.029)$ & $(0.027)$ \\
\hline \multirow[t]{2}{*}{ Private } & $0.540 * * *$ & $0.307 * * *$ & $0.328 * * *$ & $0.332 * * *$ & $0.354 * * *$ & $0.339 * * *$ & $0.338 * * *$ & $0.304 * * *$ \\
\hline & $(0.081)$ & $(0.036)$ & $(0.035)$ & $(0.034)$ & $(0.033)$ & $(0.030)$ & $(0.030)$ & $(0.028)$ \\
\hline \multirow[t]{2}{*}{$\mathrm{N}$} & 2,893 & 2,452 & 2,320 & 2,379 & 2,453 & 2,556 & 2,793 & 2,786 \\
\hline & & & & Males & & & & \\
\hline \multirow[t]{2}{*}{ SOE } & $0.158 * * *$ & $0.110 *$ & 0.060 & 0.074 & $0.155^{* * *}$ & $0.160 * * *$ & $0.177 * * *$ & $0.233 * * *$ \\
\hline & $(0.051)$ & $(0.056)$ & $(0.061)$ & $(0.056)$ & $(0.058)$ & $(0.057)$ & $(0.056)$ & $(0.054)$ \\
\hline \multirow[t]{2}{*}{ Private } & $0.328 * *$ & $0.202 * * *$ & $0.158 * *$ & $0.154 * *$ & $0.204 * * *$ & $0.179 * * *$ & $0.143 * *$ & $0.128 * *$ \\
\hline & $(0.132)$ & $(0.069)$ & $(0.072)$ & $(0.066)$ & $(0.066)$ & $(0.060)$ & $(0.059)$ & $(0.060)$ \\
\hline \multirow{3}{*}{ SOE } & & & & Females & & & & \\
\hline & $0.092 * * *$ & $0.068 * *$ & $0.110 * * *$ & $0.132 * * *$ & $0.119 * * *$ & $0.156 * * *$ & $0.156^{* * *}$ & $0.141 * * *$ \\
\hline & $(0.024)$ & $(0.034)$ & $(0.032)$ & $(0.032)$ & $(0.032)$ & $(0.031)$ & $(0.031)$ & $(0.029)$ \\
\hline \multirow[t]{2}{*}{ Private } & $0.481 * * *$ & $0.194 * * *$ & $0.233 * * *$ & $0.250 * * *$ & $0.265 * * *$ & $0.252 * * *$ & $0.288 * * *$ & $0.262 * * *$ \\
\hline & $(0.110)$ & $(0.041)$ & $(0.038)$ & $(0.038)$ & $(0.035)$ & $(0.034)$ & $(0.035)$ & $(0.031)$ \\
\hline
\end{tabular}

Notes: The table reports the mean differences in log of monthly wages between the sectors, the standard errors of the mean differences (in parentheses), and the statistical significance of the t-test on the equality of means (* significant at $10 \%, * *$ significant at 5\%, and $* * *$ significant at $1 \%$ ). Sample weights are applied for 1991 . The public sector is the comparison category. 
Table 2: Adjusted Private-Public Wage Gap by Gender and Year, OLS Estimates

\begin{tabular}{|c|c|c|c|c|c|c|c|c|}
\hline & 1991 & 1997 & 1998 & 1999 & 2000 & 2001 & 2002 & 2003 \\
\hline \multicolumn{9}{|c|}{ All workers } \\
\hline \multirow[t]{2}{*}{ SOE } & $0.076^{* * *}$ & $0.110 * * *$ & $0.123 * * *$ & $0.139 * * *$ & $0.159 * * *$ & $0.180 * * *$ & $0.169 * * *$ & $0.181 * * *$ \\
\hline & $(0.022)$ & $(0.029)$ & $(0.029)$ & $(0.027)$ & $(0.027)$ & $(0.025)$ & $(0.025)$ & $(0.023)$ \\
\hline \multirow[t]{2}{*}{ Private } & $0.482 * * *$ & $0.218 * * *$ & $0.243 * * *$ & $0.253 * * *$ & $0.278 * * *$ & $0.268 * * *$ & $0.256^{* * *}$ & $0.236 * * *$ \\
\hline & $(0.124)$ & $(0.035)$ & $(0.033)$ & $(0.032)$ & $(0.031)$ & $(0.027)$ & $(0.027)$ & $(0.025)$ \\
\hline \multirow[t]{2}{*}{$\mathrm{N}$} & 2,893 & 2,452 & 2,320 & 2,379 & 2,453 & 2,556 & 2,793 & 2,786 \\
\hline & & & & Males & & & & \\
\hline \multirow[t]{2}{*}{ SOE } & $0.080^{*}$ & $0.132 * *$ & 0.105 & $0.103^{*}$ & $0.166^{* * *}$ & $0.162 * * *$ & $0.154 * * *$ & $0.196 * * *$ \\
\hline & $(0.045)$ & $(0.059)$ & $(0.067)$ & $(0.060)$ & $(0.064)$ & $(0.054)$ & $(0.052)$ & $(0.054)$ \\
\hline \multirow[t]{2}{*}{ Private } & $0.467 * * *$ & $0.214 * * *$ & $0.181 * *$ & $0.174 * * *$ & $0.213 * * *$ & $0.205^{* * *}$ & $0.173 * * *$ & $0.165 * * *$ \\
\hline & $(0.148)$ & $(0.067)$ & $(0.071)$ & $(0.064)$ & $(0.067)$ & $(0.055)$ & $(0.052)$ & $(0.054)$ \\
\hline \multicolumn{9}{|c|}{ Females } \\
\hline \multirow[t]{2}{*}{ SOE } & $0.091 * * *$ & $0.117 * * *$ & $0.134 * * *$ & $0.149 * * *$ & $0.141 * * *$ & $0.178 * * *$ & $0.165^{* * *}$ & $0.155^{* * *}$ \\
\hline & $(0.025)$ & $(0.033)$ & $(0.031)$ & $(0.030)$ & $(0.029)$ & $(0.028)$ & $(0.029)$ & $(0.025)$ \\
\hline \multirow[t]{2}{*}{ Private } & $0.565 * * *$ & $0.257 * * *$ & $0.300 * * *$ & $0.303 * * *$ & $0.332 * * *$ & $0.312 * * *$ & $0.326^{* * *}$ & $0.316^{* * *}$ \\
\hline & $(0.209)$ & $(0.041)$ & $(0.039)$ & $(0.038)$ & $(0.035)$ & $(0.033)$ & $(0.033)$ & $(0.028)$ \\
\hline
\end{tabular}

Notes: Reported are the estimated log wage effects of the non-public types of firms relative to public firms. Robust standard errors are in parentheses; * significant at 10\%; ** significant at 5\%; *** significant at $1 \%$. The estimates are obtained from the wage function specified in equation (1) and which includes years of schooling, a gender dummy, experience, experience squared, tenure, tenure squared, a dummy for full-time job, 7 categories of firm size, and 5 regional groups. Dependent variable is log of monthly contractual wages after taxes at the primary job. 
Table 3: Adjusted Private-Public Wage Gap by Gender, Panel Estimates, 1997-2003

Panel A: Time-Invarying Wage Gap

\begin{tabular}{|c|c|c|c|c|c|c|c|c|c|}
\hline & \multicolumn{3}{|c|}{ All workers } & \multicolumn{3}{|c|}{ Males } & \multicolumn{3}{|c|}{ Females } \\
\hline & OLS(1) & OLS(2) & FE & OLS(1) & OLS(2) & FE & OLS(1) & OLS(2) & $\overline{F E}$ \\
\hline \multirow[t]{2}{*}{ SOE } & $0.153 * * *$ & $0.160 * * *$ & $0.125 * * *$ & $0.148 * * *$ & $0.155^{* * *}$ & $0.165 * * *$ & $0.150 * * *$ & $0.156^{* * *}$ & $0.087^{*}$ \\
\hline & $(0.010)$ & $(0.010)$ & $(0.037)$ & $(0.022)$ & $(0.022)$ & $(0.058)$ & $(0.011)$ & $(0.011)$ & $(0.047)$ \\
\hline \multirow[t]{2}{*}{ Private } & $0.249 * * *$ & $0.258 * * *$ & $0.214 * * *$ & $0.186^{* * *}$ & $0.205^{* * *}$ & $0.226 * * *$ & $0.310 * * *$ & $0.309 * * *$ & $0.204 * * *$ \\
\hline & $(0.011)$ & $(0.011)$ & $(0.038)$ & $(0.023)$ & $(0.023)$ & $(0.058)$ & $(0.013)$ & $(0.013)$ & $(0.050)$ \\
\hline $\mathrm{N}$ & 17,739 & 16,867 & 17,739 & 8,067 & 7,832 & 8,067 & 9,672 & 9,035 & 9,672 \\
\hline $\mathrm{R}^{2}$ & 0.316 & 0.326 & 0.331 & 0.202 & 0.220 & 0.311 & 0.292 & 0.309 & 0.360 \\
\hline $\mathrm{F}\left(\alpha_{i}=0\right)$ & $\ldots$ & $\ldots$ & 12.69 & $\ldots$ & $\ldots$ & 13.44 & $\ldots$ & $\ldots$ & 11.50 \\
\hline
\end{tabular}

Panel B: Time-Varying Wage Gap

\begin{tabular}{llllllllll}
\hline & \multicolumn{3}{c}{ All workers } & \multicolumn{3}{c}{ Males } & \multicolumn{3}{c}{ Females } \\
\cline { 2 - 5 }$(1)$ & OLS $(2)$ & FE & OLS $(1)$ & OLS $(2)$ & FE & OLS $(1)$ & OLS $(2)$ & FE \\
\hline \multirow{2}{*}{ SOE } & $0.127^{* * *}$ & $0.136^{* * *}$ & $0.130^{* * *}$ & $0.118^{* * *}$ & $0.124^{* * *}$ & $0.172^{* * *}$ & $0.127^{* * *}$ & $0.137^{* * *}$ & $0.092^{*}$ \\
& $(0.018)$ & $(0.019)$ & $(0.038)$ & $(0.040)$ & $(0.040)$ & $(0.061)$ & $(0.021)$ & $(0.022)$ & $(0.048)$ \\
Private & $0.261^{* * *}$ & $0.267^{* * *}$ & $0.223^{* * *}$ & $0.227^{* * *}$ & $0.238^{* * *}$ & $0.249^{* * *}$ & $0.279^{* * *}$ & $0.279^{* * *}$ & $0.199^{* * *}$ \\
& $(0.021)$ & $(0.022)$ & $(0.040)$ & $(0.044)$ & $(0.043)$ & $(0.063)$ & $(0.025)$ & $(0.025)$ & $(0.053)$ \\
SOE* $t$ & $0.009^{*}$ & $0.008^{*}$ & -0.002 & 0.010 & 0.011 & -0.003 & 0.007 & 0.006 & -0.002 \\
& $(0.005)$ & $(0.005)$ & $(0.004)$ & $(0.010)$ & $(0.010)$ & $(0.007)$ & $(0.005)$ & $(0.006)$ & $(0.004)$ \\
Private* $t$ & -0.003 & -0.003 & -0.003 & -0.012 & -0.010 & -0.008 & 0.010 & 0.009 & 0.001 \\
& $(0.005)$ & $(0.005)$ & $(0.004)$ & $(0.011)$ & $(0.011)$ & $(0.007)$ & $(0.006)$ & $(0.006)$ & $(0.005)$ \\
\hline $\mathrm{N}$ & 17,739 & 16,867 & 17,739 & 8,067 & 7,832 & 8,067 & 9,672 & 9,035 & 9,672 \\
$\mathrm{R}^{2}$ & 0.316 & 0.326 & 0.331 & 0.203 & 0.220 & 0.311 & 0.292 & 0.309 & 0.360 \\
\hline
\end{tabular}

Panel C: Alternative Specifications

\begin{tabular}{|c|c|c|c|c|c|c|c|c|c|}
\hline & \multicolumn{3}{|c|}{ All workers } & \multicolumn{3}{|c|}{ Males } & \multicolumn{3}{|c|}{ Females } \\
\hline & $\mathrm{RE}$ & FD & IT & $\mathrm{RE}$ & FD & IT & $\mathrm{RE}$ & FD & IT \\
\hline \multirow[t]{2}{*}{ SOE } & $0.143 * * *$ & $0.164 * *$ & $0.165 * *$ & $0.166^{* * *}$ & $0.226^{* *}$ & $0.222^{*}$ & $0.124 * * *$ & 0.130 & 0.144 \\
\hline & $(0.018)$ & $(0.067)$ & $(0.075)$ & $(0.033)$ & (0.109) & $(0.118)$ & $(0.021)$ & $(0.081)$ & $(0.090)$ \\
\hline \multirow[t]{2}{*}{ Private } & $0.241 * * *$ & $0.270 * * *$ & $0.279 * * *$ & $0.227 * * *$ & $0.314 * * *$ & $0.310 * * *$ & $0.267 * * *$ & $0.253 * * *$ & $0.281 * * *$ \\
\hline & $(0.019)$ & $(0.068)$ & $(0.076)$ & $(0.034)$ & (0.108) & $(0.116)$ & $(0.023)$ & $(0.086)$ & $(0.094)$ \\
\hline $\mathrm{N}$ & 17,739 & 13,032 & 13,032 & 8,067 & 5,870 & 5,870 & 9,672 & 7,162 & 7,162 \\
\hline $\mathrm{R}^{2}$ & 0.328 & 0.034 & 0.036 & 0.307 & 0.048 & 0.049 & 0.355 & 0.030 & 0.035 \\
\hline $\mathrm{F}\left(\alpha_{i}{ }^{\prime}=0\right)$ & $\ldots$ & $\ldots$ & 0.93 & $\ldots$ & $\ldots$ & 0.98 & $\ldots$ & $\ldots$ & 0.89 \\
\hline
\end{tabular}

Notes: Reported are the estimated log wage effects of the non-public types of firms relative to public firms for the 1997-2003 pooled data. Robust standard errors are in parentheses; * significant at $10 \% ; * *$ significant at $5 \%$; *** significant at $1 \%$. The OLS specification (1) includes years of schooling, a gender dummy, experience, experience squared, tenure, tenure squared, a dummy for full-time job, 7 categories of firm size, 5 regional groups, and 7 year dummies. The OLS specification (2) also includes marital status, number of children and parents' background such as years of schooling and occupation of both parents. FE - fixed effects estimator, RE - random effects estimator, FD - first differencing estimator, and IT - individual trend estimator. The FE, RE, FD, and IT specifications includes all time-varying variables from the specification (1) such as years of schooling, experience, experience squared, tenure, tenure squared, a dummy for full-time job, 7 categories of firm size, and 7 year dummies. $t$ is the time trend. Dependent variable is $\log$ of monthly contractual wages after taxes at the primary job. 
Table 4: Annual Rates of Entry to and Exit from the Public Sector, \%

\section{7}

\section{A. Entry Rates}

\section{SOE}

Private

Other sector

Non-employment

$\begin{array}{ll}\ldots & 1.13 \\ \ldots & 1.69 \\ \ldots & 0.56 \\ \ldots & 3.95\end{array}$

SOE

Private

Other sector

Non-employment

\section{B. Exit Rates}

\begin{tabular}{lccccccc} 
& \multicolumn{7}{c}{ Males } \\
SOE & 1.57 & 0.56 & 1.71 & 1.18 & 3.03 & 1.19 & $\ldots$ \\
Private & 3.66 & 3.39 & 6.86 & 2.37 & 1.82 & 1.19 & $\ldots$ \\
Other sector & 1.05 & 1.69 & 1.14 & 1.18 & 0.61 & 0.00 & $\ldots$ \\
Non-employment & 4.19 & 5.65 & 1.14 & 5.33 & 1.82 & 5.95 & $\ldots$ \\
& & & & & & \\
SOE & & & & & \\
Private & 0.52 & 0.69 & 0.88 & 0.36 & 1.47 & 0.00 & $\ldots$ \\
Other sector & 1.21 & 0.87 & 2.29 & 0.91 & 1.47 & 0.57 & $\ldots$ \\
Non-employment & 0.52 & 0.17 & 0.35 & 0.91 & 0.74 & 0.19 & $\ldots$ \\
\hline
\end{tabular}

Notes: Entry rate is the percentage share of the employed in the public sector at the end of year $t$ who entered the public sector in year $t$ from the corresponding sector. Exit rate is the percentage share of the employed in the public sector at the end of year $t$ who moved to the corresponding sector in year $t+1$. 
Table 5: Sensitivity of the Private-Public Wage Gap Estimates, 2003

\begin{tabular}{ccccccc}
\hline \multirow{2}{*}{ Specification } & \multicolumn{3}{c}{ SOE-Public } & \multicolumn{3}{c}{ Private-Public } \\
\cline { 2 - 6 } & $\begin{array}{c}\text { All } \\
\text { workers }\end{array}$ & Males & Females & $\begin{array}{c}\text { All } \\
\text { workers }\end{array}$ & Males & Females \\
\hline LHS - $\log ($ monthly wages) & $0.196^{* * *}$ & $0.198^{* * *}$ & $0.174^{* * *}$ & $0.287^{* * *}$ & $0.208^{* * *}$ & $0.367^{* * *}$ \\
& $(0.023)$ & $(0.054)$ & $(0.024)$ & $(0.024)$ & $(0.053)$ & $(0.027)$ \\
RHS - with union dummy & $0.190^{* * *}$ & $0.191^{* * *}$ & $0.173^{* * *}$ & $0.262^{* * *}$ & $0.174^{* * *}$ & $0.353^{* * *}$ \\
& $(0.023)$ & $(0.054)$ & $(0.024)$ & $(0.026)$ & $(0.054)$ & $(0.028)$ \\
LHS - $\log$ (hourly wages) & $0.160^{* * *}$ & $0.163^{* * *}$ & $0.147^{* * *}$ & $0.193^{* * *}$ & $0.137^{* * *}$ & $0.261^{* * *}$ \\
& $(0.023)$ & $(0.050)$ & $(0.026)$ & $(0.025)$ & $(0.050)$ & $(0.029)$ \\
LHS - log(hourly wages) & $0.161^{* * *}$ & $0.170^{* * *}$ & $0.141^{* * *}$ & $0.204^{* * *}$ & $0.149^{* * *}$ & $0.270^{* * *}$ \\
(full-time employees) & $(0.024)$ & $(0.051)$ & $(0.026)$ & $(0.025)$ & $(0.051)$ & $(0.030)$ \\
LHS - log(expected & $0.153^{* * *}$ & $0.157^{* * *}$ & $0.139^{* * *}$ & $0.178^{* * *}$ & $0.123^{* *}$ & $0.246^{* * *}$ \\
hourly wage) & $(0.023)$ & $(0.050)$ & $(0.026)$ & $(0.025)$ & $(0.050)$ & $(0.029)$ \\
\hline
\end{tabular}

Notes: $\mathrm{N}=2561$ (2416 for full-time employees). Reported are the estimated log wage effects of the non-public types of firms relative to public firms in five OLS specifications. Robust standard errors are in parentheses; * significant at 10\%; ** significant at $5 \% ; * * *$ significant at $1 \%$. All five specifications include years of schooling, a gender dummy, experience, experience squared, tenure, tenure squared, a dummy for full-time job, 7 categories of firm size, and 5 regional groups. The baseline estimates (in the first row) slightly differ from those in Table 3 because of the different sample sizes. Specifically, we exclude respondents with missing observations on hours of work and also respondents earning less than two thirds of a minimum hourly wage $(\approx 0.734 \mathrm{UAH})$. 
Table 6: Incidence of Fringe Benefits by Sector and Gender, 2003 (percent)

\begin{tabular}{|c|c|c|c|c|c|c|}
\hline & \multicolumn{3}{|c|}{ Males } & \multicolumn{3}{|c|}{ Females } \\
\hline & Public & SOE & Private & Public & SOE & Private \\
\hline Regular paid vacation & 96.32 & 94.56 & 69.32 & 97.88 & 95.50 & 64.12 \\
\hline Paid sick leave & 92.65 & 93.59 & 63.59 & 96.39 & 94.32 & 59.35 \\
\hline Paid maternity leave and child care & & & & & & \\
\hline leave & 77.21 & 66.60 & 44.36 & 88.11 & 79.84 & 48.85 \\
\hline $\begin{array}{l}\text { Free treatment in an enterprise } \\
\text { polyclinic and other health subsidies }\end{array}$ & 19.85 & 26.21 & 13.04 & 20.81 & 20.74 & 13.17 \\
\hline $\begin{array}{l}\text { Payment for travel to sanatoria, } \\
\text { tourist bases, or children camps } \\
\text { Free child care in an enterprise }\end{array}$ & 22.79 & 32.82 & 14.31 & 26.11 & 29.55 & 14.69 \\
\hline $\begin{array}{l}\text { kindergarten and other formal child } \\
\text { care subsidies }\end{array}$ & 1.47 & 5.44 & 3.18 & 2.12 & 1.96 & 1.72 \\
\hline $\begin{array}{l}\text { Free food, discounted food, or food } \\
\text { subsidies }\end{array}$ & 2.94 & 5.44 & 3.02 & 0.85 & 1.96 & 4.20 \\
\hline Transportation subsidies & 4.41 & 12.04 & 3.97 & 3.40 & 9.00 & 4.01 \\
\hline Enterprise-paid training & 19.85 & 26.21 & 10.33 & 30.57 & 24.07 & 11.64 \\
\hline Loans and credit & 0.00 & 8.93 & 6.04 & 2.76 & 8.02 & 5.92 \\
\hline $\begin{array}{l}\text { Possibilities to rent/purchase garden } \\
\text { and land plot at below market prices }\end{array}$ & 1.47 & 6.21 & 2.07 & 1.91 & 4.31 & 4.20 \\
\hline $\begin{array}{l}\text { Equipment for additional earnings } \\
\text { and private needs }\end{array}$ & 0.00 & 0.78 & 0.64 & 0.21 & 0.00 & 0.19 \\
\hline Housing subsidies & 8.82 & 6.21 & 3.34 & 8.07 & 5.28 & 3.82 \\
\hline No fringe benefits & 2.94 & 2.33 & 22.73 & 1.27 & 2.74 & 30.15 \\
\hline
\end{tabular}

Note: The table shows the percentage of workers reporting a given type of fringe benefit at their primary job. 
Table 7: Job Separations by Sector and Year

$1991-1997-1998$

A. Quits

\begin{tabular}{|c|c|c|c|c|c|c|c|}
\hline \multicolumn{8}{|c|}{ Males } \\
\hline Public & 0.104 & 0.137 & 0.083 & 0.125 & 0.101 & 0.112 & 0.074 \\
\hline SOE & 0.105 & 0.127 & 0.104 & 0.119 & 0.091 & 0.112 & 0.042 \\
\hline Private & 0.214 & 0.144 & 0.101 & 0.134 & 0.105 & 0.116 & 0.067 \\
\hline \multicolumn{8}{|c|}{ Females } \\
\hline Public & 0.092 & 0.090 & 0.081 & 0.073 & 0.083 & 0.069 & 0.024 \\
\hline SOE & 0.100 & 0.094 & 0.078 & 0.072 & 0.070 & 0.093 & 0.040 \\
\hline Private & 0.125 & 0.092 & 0.125 & 0.101 & 0.124 & 0.139 & 0.049 \\
\hline \multicolumn{8}{|c|}{ B. Layoffs } \\
\hline \multicolumn{8}{|c|}{ Males } \\
\hline Public & 0.040 & 0.048 & 0.019 & 0.025 & 0.000 & 0.016 & 0.000 \\
\hline SOE & 0.042 & 0.048 & 0.046 & 0.045 & 0.028 & 0.064 & 0.010 \\
\hline Private & 0.000 & 0.054 & 0.042 & 0.028 & 0.036 & 0.052 & 0.024 \\
\hline \multicolumn{8}{|c|}{ Females } \\
\hline Public & 0.012 & 0.015 & 0.024 & 0.021 & 0.018 & 0.019 & 0.004 \\
\hline SOE & 0.030 & 0.064 & 0.052 & 0.052 & 0.049 & 0.026 & 0.012 \\
\hline Private & 0.063 & 0.109 & 0.070 & 0.048 & 0.041 & 0.056 & 0.020 \\
\hline
\end{tabular}

Note: The table shows the share of workers that quit their job or being laid off during the next year. 
Table 8: Determinants of the Probability of Separations, 1997-2003

\begin{tabular}{|c|c|c|}
\hline & Layoffs & Quits \\
\hline \multirow[t]{2}{*}{ SOE } & $0.029 * * *$ & 0.003 \\
\hline & $(0.005)$ & $(0.006)$ \\
\hline \multirow[t]{2}{*}{ Private } & $0.034 * * *$ & 0.006 \\
\hline & $(0.006)$ & $(0.007)$ \\
\hline \multirow[t]{2}{*}{ Schooling (years) } & $-0.002 * * *$ & $-0.002 * * *$ \\
\hline & $(0.001)$ & $(0.001)$ \\
\hline \multirow[t]{2}{*}{ Male } & -0.005 & $0.014 * * *$ \\
\hline & $(0.003)$ & $(0.005)$ \\
\hline \multirow[t]{2}{*}{ Potential experience (years) } & 0.000 & $-0.010 * * *$ \\
\hline & $(0.001)$ & $(0.001)$ \\
\hline \multirow[t]{2}{*}{ Potential experience squared $/ 1000$} & -0.011 & $0.222 * * *$ \\
\hline & $(0.012)$ & $(0.018)$ \\
\hline \multirow{2}{*}{ Tenure (years) } & $-0.001 *$ & $-0.004 * * *$ \\
\hline & $(0.000)$ & $(0.001)$ \\
\hline \multirow{2}{*}{ Tenure squared $/ 1000$} & 0.018 & $0.110 * * *$ \\
\hline & $(0.015)$ & $(0.024)$ \\
\hline \multirow[t]{2}{*}{ Full-time job } & $-0.018 * *$ & 0.013 \\
\hline & $(0.007)$ & $(0.009)$ \\
\hline \multicolumn{3}{|l|}{ Firm size } \\
\hline \multirow[t]{2}{*}{$10-49$} & -0.002 & 0.000 \\
\hline & $(0.005)$ & $(0.008)$ \\
\hline \multirow[t]{2}{*}{$50-99$} & -0.005 & $-0.015^{*}$ \\
\hline & $(0.005)$ & $(0.008)$ \\
\hline \multirow[t]{2}{*}{$100-499$} & $-0.011 * *$ & $-0.022 * * *$ \\
\hline & $(0.004)$ & $(0.007)$ \\
\hline \multirow[t]{2}{*}{$500-599$} & -0.007 & $-0.024 * * *$ \\
\hline & $(0.006)$ & $(0.009)$ \\
\hline \multirow[t]{2}{*}{$1000+$} & -0.007 & $-0.023 * * *$ \\
\hline & $(0.005)$ & $(0.008)$ \\
\hline \multirow[t]{2}{*}{ No information } & -0.001 & $0.026 * *$ \\
\hline & $(0.006)$ & $(0.011)$ \\
\hline $\mathrm{N}$ & 14,953 & 14,953 \\
\hline
\end{tabular}

Notes: The reported marginal effects are obtained from the probit estimates. The dependent variables are dummies indicating whether an individual is laid off (column 1) or quit (column 2) during the next year. Robust standard errors are in parentheses; * significant at $10 \%$; * significant at $5 \%$; *** significant at $1 \%$. The omitted categories are public organizations and 1-9 employees (firm size). Regional and year dummies are included in the probit estimates but not shown here. 
Table 9: Dispersion of Wages

Panel A: Dispersion of Wages by Year

\begin{tabular}{|c|c|c|c|c|c|c|c|c|}
\hline & 1991 & 1997 & 1998 & 1999 & 2000 & 2001 & 2002 & 2003 \\
\hline \multicolumn{9}{|c|}{ Standard deviation of log of monthly wage } \\
\hline Public & 0.480 & 0.553 & 0.539 & 0.533 & 0.511 & 0.495 & 0.512 & 0.473 \\
\hline SOE & 0.539 & 0.602 & 0.574 & 0.551 & 0.572 & 0.567 & 0.584 & 0.570 \\
\hline Private & 0.829 & 0.651 & 0.633 & 0.634 & 0.633 & 0.609 & 0.636 & 0.610 \\
\hline \multicolumn{9}{|c|}{ 90-10 wage differentials } \\
\hline Public & 1.139 & 1.273 & 1.139 & 1.227 & 1.099 & 1.068 & 1.070 & 1.019 \\
\hline SOE & 1.358 & 1.322 & 1.358 & 1.308 & 1.310 & 1.427 & 1.357 & 1.386 \\
\hline Private & 1.792 & 1.609 & 1.492 & 1.609 & 1.526 & 1.466 & 1.455 & 1.386 \\
\hline
\end{tabular}

Panel B: Dispersion of Wages in the Pooled Sample, 1997-2003

\begin{tabular}{|c|c|c|c|c|c|}
\hline & \multicolumn{3}{|c|}{$\begin{array}{l}\text { Standard Deviation of } \\
\text { Log of Monthly Wage }\end{array}$} & \multicolumn{2}{|c|}{$\Delta$ Wage Gap } \\
\hline & Public & SOE & Private & $\begin{array}{l}\text { SOE- } \\
\text { Public }\end{array}$ & $\begin{array}{l}\text { Private- } \\
\text { Public }\end{array}$ \\
\hline \multicolumn{6}{|c|}{ Variation in $\ln w_{i t}$ (raw data adjusted for inflation) } \\
\hline All & 0.508 & 0.556 & 0.629 & 0.013 & 0.035 \\
\hline Males & 0.583 & 0.538 & 0.642 & $\ldots$ & 0.018 \\
\hline Females & 0.442 & 0.490 & 0.569 & 0.011 & 0.032 \\
\hline \multicolumn{6}{|c|}{ Variation in conditional $\ln w_{i t}($ OLS residuals $)$} \\
\hline All & 0.427 & 0.471 & 0.570 & 0.010 & 0.036 \\
\hline Males & 0.518 & 0.492 & 0.597 & $\ldots$ & 0.022 \\
\hline Females & 0.387 & 0.446 & 0.524 & 0.012 & 0.032 \\
\hline \multicolumn{6}{|c|}{ Inter-temporal variation in conditional $\ln w_{i t}($ FE residuals $)$} \\
\hline All & 0.259 & 0.303 & 0.281 & 0.006 & 0.003 \\
\hline Males & 0.273 & 0.317 & 0.284 & 0.007 & 0.002 \\
\hline Females & 0.255 & 0.289 & 0.277 & 0.005 & 0.003 \\
\hline
\end{tabular}

Notes: $\Delta$ Wage gap=the change in the wage gap that compensates the differences in the dispersion of wages between the sectors $(\gamma=1.5)$. The dispersion of conditional log of monthly wage is computed on the basis of the OLS residuals obtained from equation (1). Inter-temporal variation on conditional log wage is approximated by the standard deviation of residuals estimated from equation (2), with individual and year fixed effects included. 
Table 10: Job Satisfaction, Bonuses, and Multiple Job Holding, 2003

\begin{tabular}{|c|c|c|c|c|c|}
\hline \multirow{2}{*}{$\begin{array}{l}\text { Dependent } \\
\text { Variables: }\end{array}$} & \multicolumn{2}{|c|}{ Coeff. (Std. Err.) } & \multirow{2}{*}{$\begin{array}{c}\text { Mean } \\
\text { (Std.Dev.) }\end{array}$} & \multirow{2}{*}{$\begin{array}{c}\mathbf{R}^{2} \text { or } \\
\text { Pseudo } \mathbf{R}^{2}\end{array}$} & \multirow{2}{*}{$\mathbf{N}$} \\
\hline & SOE & Private & & & \\
\hline $\begin{array}{l}\text { Job satisfaction } \\
\text { /Ordered Probit/ }\end{array}$ & $\begin{array}{l}0.171 * * * \\
(0.058)\end{array}$ & $\begin{array}{l}-0.057 \\
(0.059)\end{array}$ & $\begin{array}{c}3.333 \\
(1.216)\end{array}$ & 0.014 & 2766 \\
\hline $\begin{array}{l}\text { Bonus: } 13^{\text {th }} \text { salary } \\
\text { /Probit/ }\end{array}$ & $\begin{array}{l}0.064 * * * \\
(0.017)\end{array}$ & $\begin{array}{l}-0.020 \\
(0.015)\end{array}$ & 0.106 & 0.144 & 2773 \\
\hline $\begin{array}{l}\text { Bonus: performance-based } \\
\text { /Probit/ }\end{array}$ & $\begin{array}{l}0.080^{* * *} \\
(0.024)\end{array}$ & $\begin{array}{l}-0.003 \\
(0.024)\end{array}$ & 0.262 & 0.042 & 2773 \\
\hline $\begin{array}{l}\text { Bonus for work conditions } \\
\text { /Probit/ }\end{array}$ & $\begin{array}{c}0.016 \\
(0.011)\end{array}$ & $\begin{array}{l}-0.018^{*} \\
(0.010)\end{array}$ & 0.051 & 0.082 & 2773 \\
\hline $\begin{array}{l}\text { Bonus: profit sharing } \\
\text { /Probit/ }\end{array}$ & $\begin{array}{c}0.011 \\
(0.007)\end{array}$ & $\begin{array}{l}0.015^{* *} \\
(0.007)\end{array}$ & 0.011 & 0.095 & 2608 \\
\hline $\begin{array}{l}\text { Bonus: other compensation } \\
\text { /Probit/ }\end{array}$ & $\begin{array}{c}0.004 \\
(0.009)\end{array}$ & $\begin{array}{l}-0.011 \\
(0.009)\end{array}$ & 0.043 & 0.048 & 2773 \\
\hline $\begin{array}{l}\text { No bonuses last year } \\
\text { /Probit/ }\end{array}$ & $\begin{array}{l}-0.100 * * * \\
(0.027)\end{array}$ & $\begin{array}{c}0.041 \\
(0.027)\end{array}$ & 0.629 & 0.063 & 2773 \\
\hline $\begin{array}{l}\text { Had a secondary job } \\
\text { /Probit/ }\end{array}$ & $\begin{array}{l}-0.006 \\
(0.006)\end{array}$ & $\begin{array}{l}-0.000 \\
(0.006)\end{array}$ & 0.023 & 0.064 & 2785 \\
\hline $\begin{array}{l}\text { Wage from primary and } \\
\text { secondary jobs /OLS/ }\end{array}$ & $\begin{array}{l}0.196 * * * \\
(0.029)\end{array}$ & $\begin{array}{l}0.236 * * * \\
(0.031)\end{array}$ & $\begin{array}{c}5.520 \\
(0.642)\end{array}$ & 0.250 & 2784 \\
\hline
\end{tabular}

Notes: Robust standard errors are in parentheses; * significant at 10\%; $* *$ significant at $5 \%$; *** significant at $1 \%$. Marginal effects are reported for probit estimates. All ten equations include years of schooling, a gender dummy, experience, experience squared, tenure, tenure squared, a dummy for full-time job, 7 categories of firm size, and 5 regional groups. The omitted category is public organizations. Job satisfaction is defined on a scale from 1 (fully unsatisfied) to 5 (fully satisfied). 
Table 11: Household Income, Expenditures, and Wealth, 2003

\begin{tabular}{|c|c|c|c|c|c|c|c|c|c|}
\hline & $\begin{array}{c}\text { Contractual } \\
\text { wage }\end{array}$ & $\begin{array}{c}\text { Actual } \\
\text { wage }\end{array}$ & $\begin{array}{c}\text { Total } \\
\text { earnings }\end{array}$ & $\begin{array}{c}\text { HH } \\
\text { income }\end{array}$ & $\begin{array}{c}\text { Non- } \\
\text { durables }\end{array}$ & Durables & $\begin{array}{l}\text { Value of } \\
\text { housing }\end{array}$ & $\begin{array}{c}\text { Housing } \\
\text { space }\end{array}$ & C-Y gap \\
\hline Mean (depvar) & 420.7 & 414.6 & 497.3 & 526.5 & 623.2 & 2957.1 & 8508.5 & 60.6 & 0.045 \\
\hline St.dev.(depvar) & 313.9 & 317.2 & 391.1 & 337.3 & 765.2 & 5976.0 & 9340.0 & 25.1 & 0.800 \\
\hline Units & UAH & UAH & UAH & UAH & UAH & UAH & UAH & $\mathrm{sq} \mathrm{m}$ & $\log$ ratio \\
\hline \multirow[t]{2}{*}{ Reference period } & month & month & month & month & month & year & stock & stock & month \\
\hline & (1) OLS & (2) OLS & (3) OLS & (4) OLS & (5) OLS & (6) Tobit & (7) Tobit & (8) OLS & (9) OLS \\
\hline \multicolumn{10}{|l|}{ No. of HH earners in } \\
\hline \multirow[t]{2}{*}{ SOEs } & $0.118^{* * *}$ & $0.102 * * *$ & $0.124 * * *$ & $0.104 * * *$ & 0.019 & 0.170 & $-0.645 * * *$ & $-2.373 * *$ & $-0.072 * *$ \\
\hline & $(0.022)$ & $(0.023)$ & $(0.029)$ & $(0.021)$ & $(0.036)$ & $(0.977)$ & $(0.244)$ & $(1.067)$ & $(0.035)$ \\
\hline \multirow[t]{2}{*}{ Private sector } & $0.166^{* * *}$ & $0.163 * * *$ & $0.175 * * *$ & $0.135^{* * *}$ & 0.057 & -0.118 & -0.377 & -0.550 & $-0.073 * *$ \\
\hline & $(0.023)$ & $(0.024)$ & $(0.031)$ & $(0.022)$ & $(0.038)$ & $(1.033)$ & $(0.252)$ & (1.118) & $(0.037)$ \\
\hline \multirow[t]{2}{*}{ Other sectors } & -0.005 & -0.003 & -0.041 & 0.019 & $-0.182 * * *$ & 1.262 & -0.112 & 1.210 & $-0.170 * * *$ \\
\hline & $(0.036)$ & $(0.041)$ & $(0.053)$ & $(0.035)$ & $(0.060)$ & $(1.590)$ & $(0.416)$ & $(1.854)$ & $(0.058)$ \\
\hline \multirow[t]{2}{*}{ No. of HH earners } & $0.532 * * *$ & $0.511 * * *$ & $0.283 * * *$ & $0.434 * * *$ & $0.087 * *$ & -1.081 & $0.552 * *$ & -0.291 & $-0.345 * * *$ \\
\hline & $(0.022)$ & $(0.024)$ & $(0.030)$ & $(0.022)$ & $(0.038)$ & $(1.037)$ & $(0.253)$ & $(1.117)$ & $(0.037)$ \\
\hline \multirow[t]{2}{*}{ No. of $\mathrm{HH}$ members } & $\ldots$ & $\ldots$ & $\ldots$ & $-0.018^{*}$ & $0.138 * * *$ & -0.056 & $0.287 * *$ & $6.425 * * *$ & $0.141 * * *$ \\
\hline & & & & $(0.010)$ & $(0.017)$ & $(0.444)$ & $(0.120)$ & $(0.502)$ & $(0.016)$ \\
\hline \multirow{2}{*}{$\begin{array}{c}\text { Average schooling } \\
\text { of HH earners }\end{array}$} & $0.051 * * *$ & $0.048 * * *$ & $0.055 * * *$ & $0.041 * * *$ & $0.038 * * *$ & 0.315 & $0.187 * * *$ & $0.424 * *$ & -0.003 \\
\hline & $(0.004)$ & $(0.005)$ & $(0.006)$ & $(0.004)$ & $(0.007)$ & $(0.192)$ & $(0.050)$ & $(0.214)$ & $(0.007)$ \\
\hline Share of males among & $0.250 * * *$ & $0.266 * * *$ & $0.110 * * *$ & $0.189 * * *$ & 0.031 & $1.916^{*}$ & -0.029 & $2.475 * *$ & $-0.154 * * *$ \\
\hline HH earners & $(0.024)$ & $(0.026)$ & $(0.034)$ & $(0.023)$ & $(0.040)$ & $(1.079)$ & $(0.284)$ & $(1.226)$ & $(0.039)$ \\
\hline $\mathrm{N}$ & 2272 & 2180 & 2081 & 2202 & 2000 & $2234[241]$ & $1337[1092]$ & 2047 & 1949 \\
\hline
\end{tabular}

Notes: Household is the unit of observation. Except for tobit, robust standard errors are in parentheses; * significant at 10\%; ** significant at 5\%; *** significant at $1 \%$. In tobit specifications zero values are replaced by 1 , observations with $\log ($ depvar $)>0$ is in brackets and their conditional mean is reported in row 1 . To reduce the influence of outliers in earnings and consumption functions, the OLS is performed as a Huber robust regression, with lower weights given to influential observations. All income and expenditures measures are used in logarithmic form. HH denotes household. UAH is Ukrainian currency. All specifications include individual covariates from equation (1) that are averaged for household wage earners. Specifications related to the whole household (as opposed to wage earners) also include controls for HH composition such as number of HH members, number of children, and number of retirees (specifications 4 through 9 ). The consumption-income gap (C-Y gap) is defined in the text. 
Table 12: The Consumption-Income Gap by Subsector and Major Occupational Group of the Public Sector, Head of Household Specification, 2003

\begin{tabular}{|c|c|c|c|c|}
\hline & (1) & $(2)$ & (3) & (4) \\
\hline Private sector - all occupations & omitted & omitted & omitted & $\ldots$ \\
\hline Public sector - all occupations & $\begin{array}{l}0.118 * * \\
(0.048)\end{array}$ & & & \\
\hline \multicolumn{5}{|l|}{ Public sector by subsector: } \\
\hline Public administration & & $\begin{array}{c}0.238 * * \\
(0.107)\end{array}$ & & \\
\hline Healthcare & & $\begin{array}{l}0.247 * * * \\
(0.073)\end{array}$ & & \\
\hline Education & & $\begin{array}{c}0.043 \\
(0.065)\end{array}$ & & \\
\hline Other public sector industries & & $\begin{array}{l}-0.086 \\
(0.106)\end{array}$ & & \\
\hline \multicolumn{5}{|l|}{ Public sector by occupation: } \\
\hline Managers & & & $\begin{array}{l}0.247 * * \\
(0.120)\end{array}$ & $\begin{array}{l}0.244 * * \\
(0.120)\end{array}$ \\
\hline Health professionals \& associates & & & $\begin{array}{l}0.226^{* * *} \\
(0.086)\end{array}$ & $\begin{array}{l}0.225^{* * *} * \\
(0.086)\end{array}$ \\
\hline Teaching professionals \& associates & & & $\begin{array}{c}0.017 \\
(0.080)\end{array}$ & $\begin{array}{c}0.015 \\
(0.081)\end{array}$ \\
\hline Other public sector occupations & & & $\begin{array}{c}0.102 \\
(0.064)\end{array}$ & $\begin{array}{c}0.101 \\
(0.065)\end{array}$ \\
\hline \multicolumn{5}{|l|}{ Private sector by occupation: } \\
\hline Managers & & & & $\begin{array}{c}0.023 \\
(0.091)\end{array}$ \\
\hline Health professionals \& associates & & & & $\begin{array}{l}-0.366 \\
(0.284)\end{array}$ \\
\hline Teaching professionals \& associates & & & & $\begin{array}{c}0.376 \\
(0.692)\end{array}$ \\
\hline Other private sector occupations & & & & omitted \\
\hline SOE & $\begin{array}{c}0.006 \\
(0.038)\end{array}$ & $\begin{array}{c}0.006 \\
(0.037)\end{array}$ & $\begin{array}{c}0.007 \\
(0.038)\end{array}$ & $\begin{array}{c}0.006 \\
(0.038)\end{array}$ \\
\hline Other sectors & $\begin{array}{l}-0.139 * * \\
(0.068)\end{array}$ & $\begin{array}{l}-0.139 * * \\
(0.068)\end{array}$ & $\begin{array}{l}-0.139 * * \\
(0.068)\end{array}$ & $\begin{array}{l}-0.140 * * \\
(0.068)\end{array}$ \\
\hline
\end{tabular}

Notes: $\mathrm{N}=1938$. Household is the unit of observation. Household head is the person with largest earnings. Robust standard errors are in parentheses; * significant at 10\%; ** significant at 5\%; *** significant at $1 \%$. To reduce the influence of outliers in earnings and consumption functions, the OLS is performed as a Huber robust regression, with lower weights given to influential observations. All specifications include individual covariates for the $\mathrm{HH}$ head from equation (1) and controls for $\mathrm{HH}$ composition such as number of $\mathrm{HH}$ members, number of children, and number of retirees. The dependent variable - consumption-income gap - is defined in the text. 
Table 13: Estimates of Bribery in the Public Sector, 2003

\begin{tabular}{|c|c|c|c|c|}
\hline \multirow[b]{2}{*}{ Method } & \multirow{2}{*}{$\begin{array}{c}\text { Wage Gap } \\
\text { Estimate }\end{array}$} & \multicolumn{3}{|c|}{ Aggregate Bribery } \\
\hline & & mln UAH & $\%$ of GDP & $\begin{array}{c}\% \text { of Wage } \\
\text { Bill }\end{array}$ \\
\hline \multicolumn{5}{|c|}{ SOE vs. Public } \\
\hline Unconditional monthly wage, 2003 & 0.286 & 4,132 & 1.56 & 6.36 \\
\hline OLS, monthly wage, 1997-2003 & 0.153 & 2,063 & 0.78 & 3.18 \\
\hline Fixed effect, monthly wage, 1997-2003 & 0.125 & 1,662 & 0.63 & 2.56 \\
\hline Individual-specific trend, monthly wage, 1997-2003 & 0.165 & 2,239 & 0.85 & 3.45 \\
\hline OLS, hourly wage, 2003 & 0.160 & 2,165 & 0.82 & 3.33 \\
\hline OLS, expected hourly wage, 2003 & 0.153 & 2,063 & 0.78 & 3.18 \\
\hline Quantile regression, hourly wage, 2003 & 0.185 & 2,542 & 0.96 & 3.91 \\
\hline Quantile regression, expected hourly wage, 2003 & 0.178 & 2,438 & 0.92 & 3.75 \\
\hline \multicolumn{5}{|c|}{ Private vs. Public } \\
\hline Unconditional monthly wage, 2003 & 0.304 & 4,434 & 1.68 & 6.82 \\
\hline OLS, monthly wage, $1997-2003$ & 0.249 & 3,528 & 1.34 & 5.43 \\
\hline Fixed effect, monthly wage, 1997-2003 & 0.214 & 2,978 & 1.13 & 4.58 \\
\hline Individual-specific trend, monthly wage, $1997-2003$ & 0.279 & 4,016 & 1.52 & 6.18 \\
\hline OLS, hourly wage, 2003 & 0.193 & 2,657 & 1.01 & 4.09 \\
\hline OLS, expected hourly wage, 2003 & 0.178 & 2,431 & 0.92 & 3.74 \\
\hline Quantile regression, hourly wage, 2003 & 0.238 & 3,346 & 1.27 & 5.15 \\
\hline Quantile regression, expected hourly wage, 2003 & 0.221 & 3,094 & 1.17 & 4.76 \\
\hline
\end{tabular}

Notes: The amount of bribes is computed according to the methodology described in Section 6. In addition to the estimated wage gap, we also use the following data for 2003: GDP=264,165 million $\mathrm{UAH} ; N_{b}=3,741$ million people, average before-tax monthly wage of the public sector employee $=351 \mathrm{UAH}$; total wage bill $=64,966 \mathrm{mln} \mathrm{UAH}$, effective income tax rate $=20.8 \%$ (State Statistics Committee of Ukraine 2003). The wage gap estimate for quantile regressions is a weighted average across percentiles, with conditional hourly wage rate used as a weight. 
Figure 1: Quantile Estimates of the Private-Public Wage Gap by Gender and Year
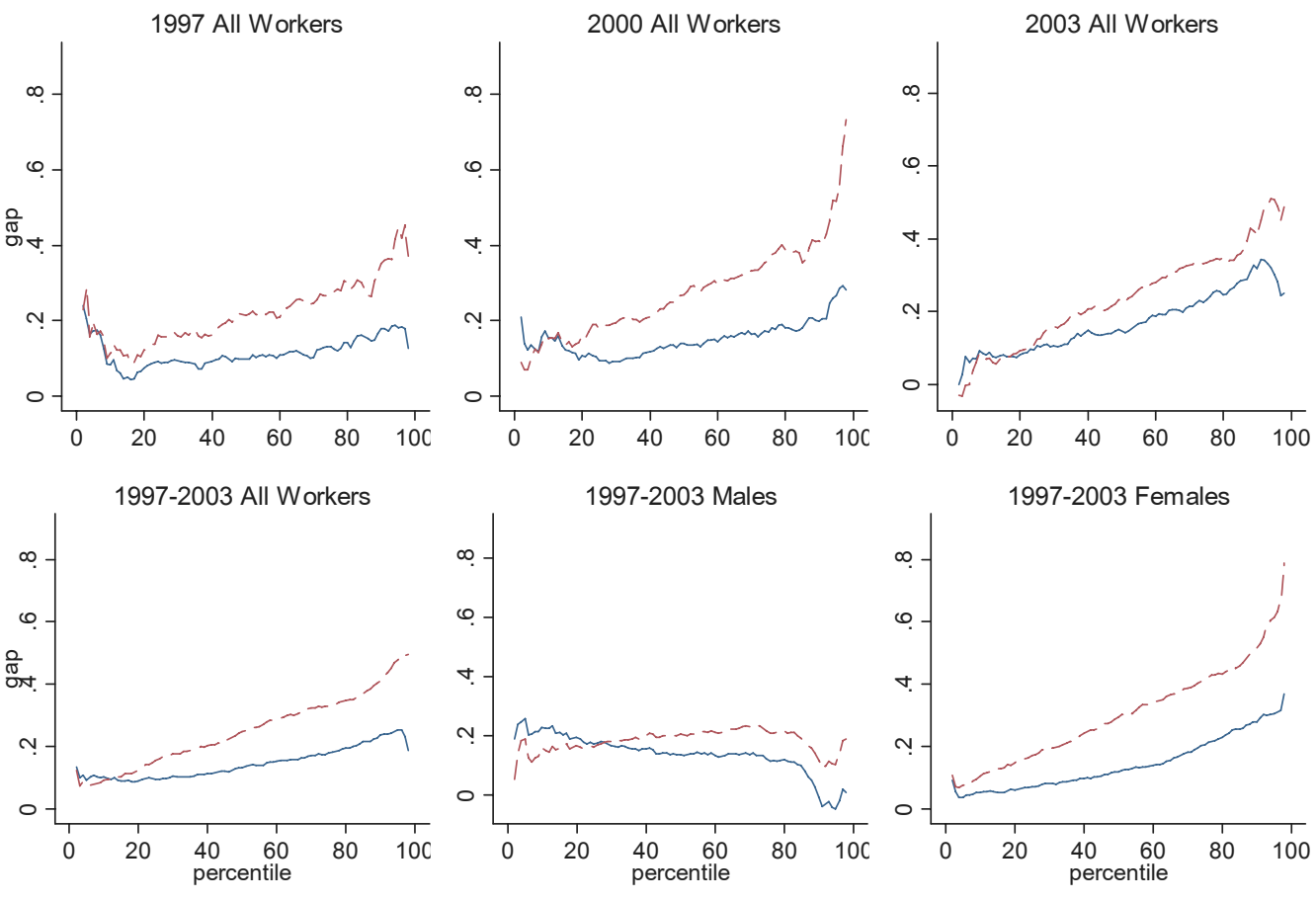
Figure 2: Counterfactual Private-Public Wage Gap by Gender, 1997-2003
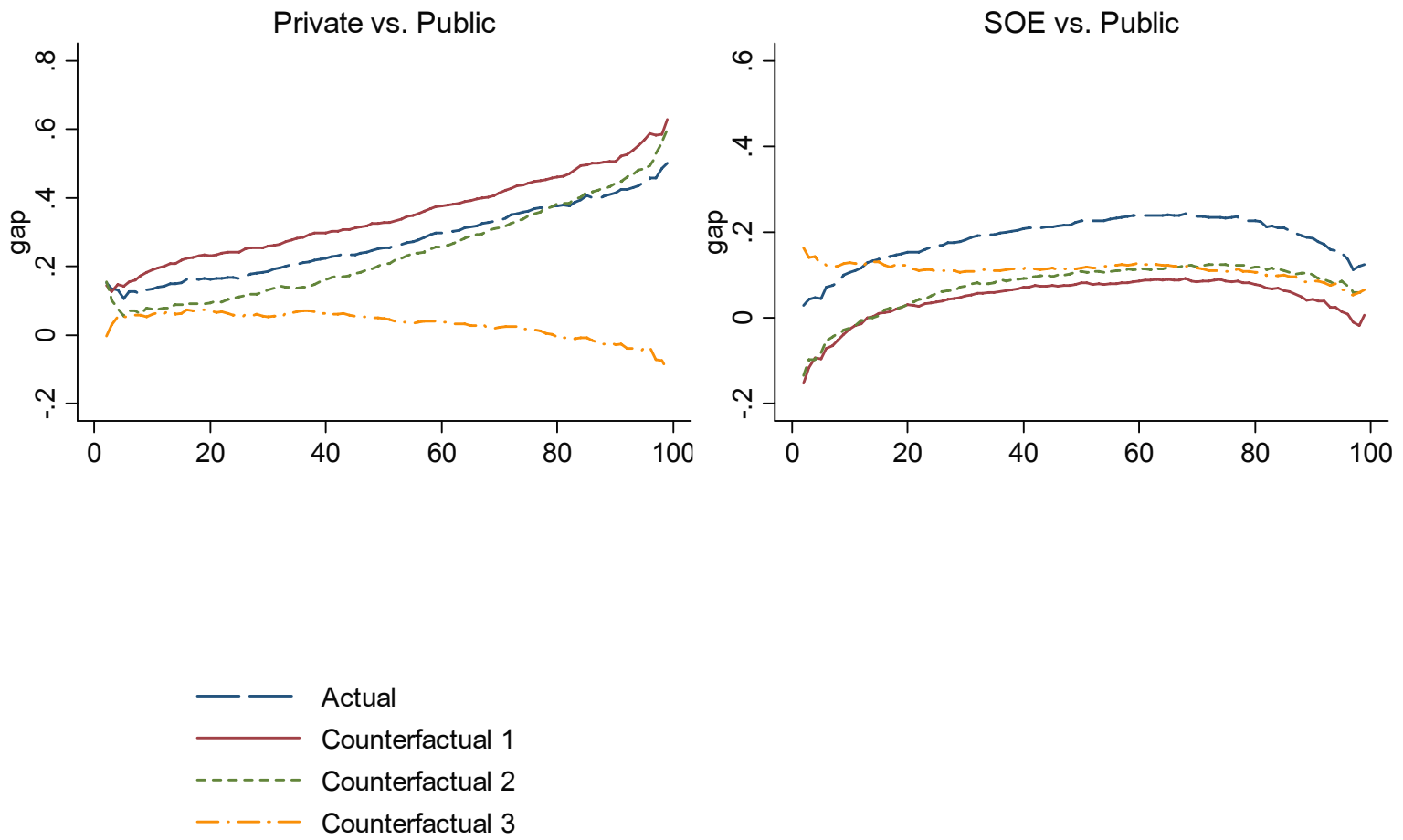

Notes: Counterfactual 1 = how much would the private sector employee gain (lose) if he/she were to move to the public sector. Counterfactual $2=$ how much would the public sector employee gain (lose) if he/she were to move to the private sector. Counterfactual $3=$ the estimated wage differences between the private sector employees and the public sector employee if he/she had $\beta$ s from the private sector. 
Figure 3: Quantile Estimates of the Private-Public Wage Gap, Monthly vs. Hourly Wages
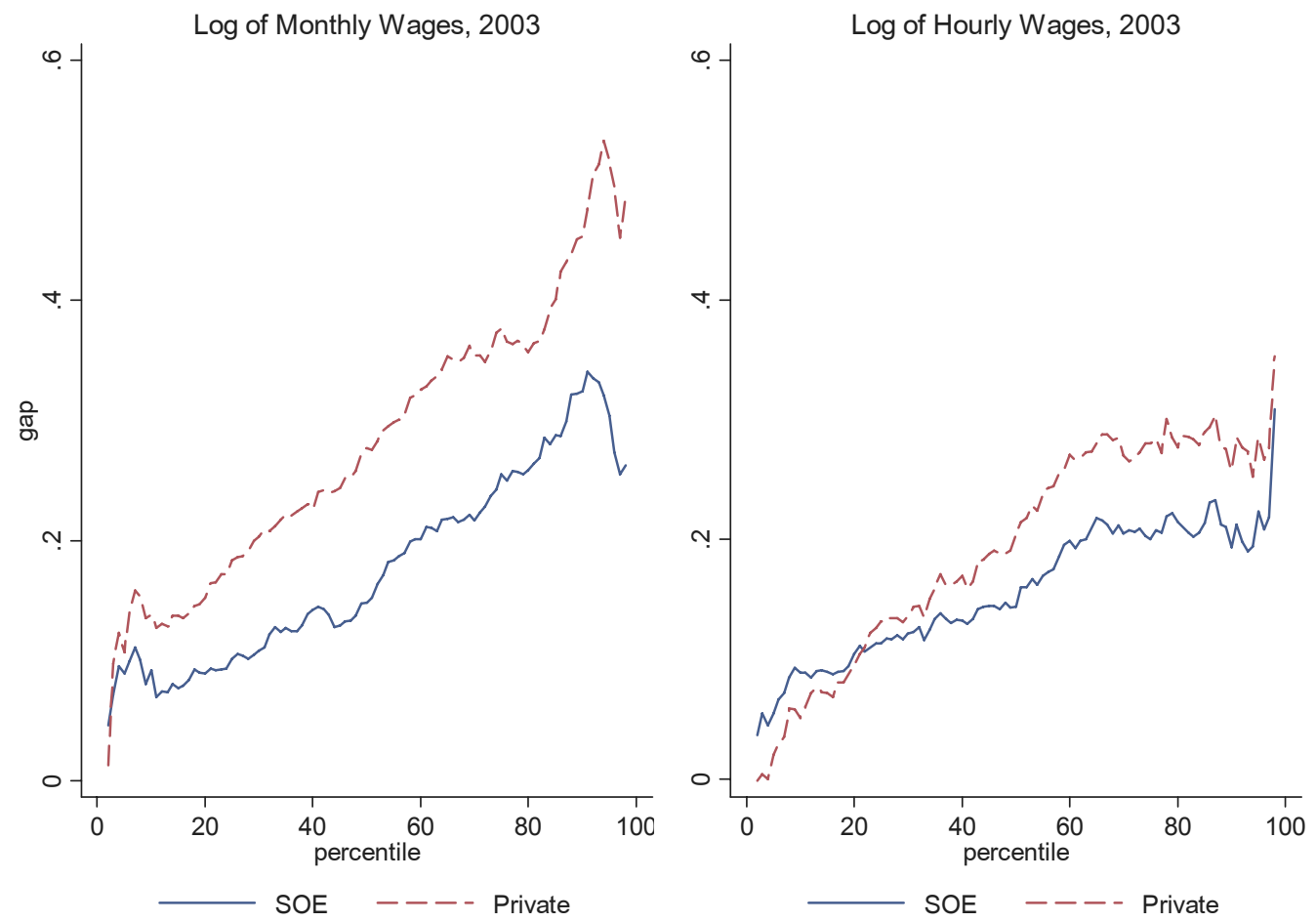
Figure 4: Incidence of Fringe Benefits by Decile of Conditional Log Wage, 2003
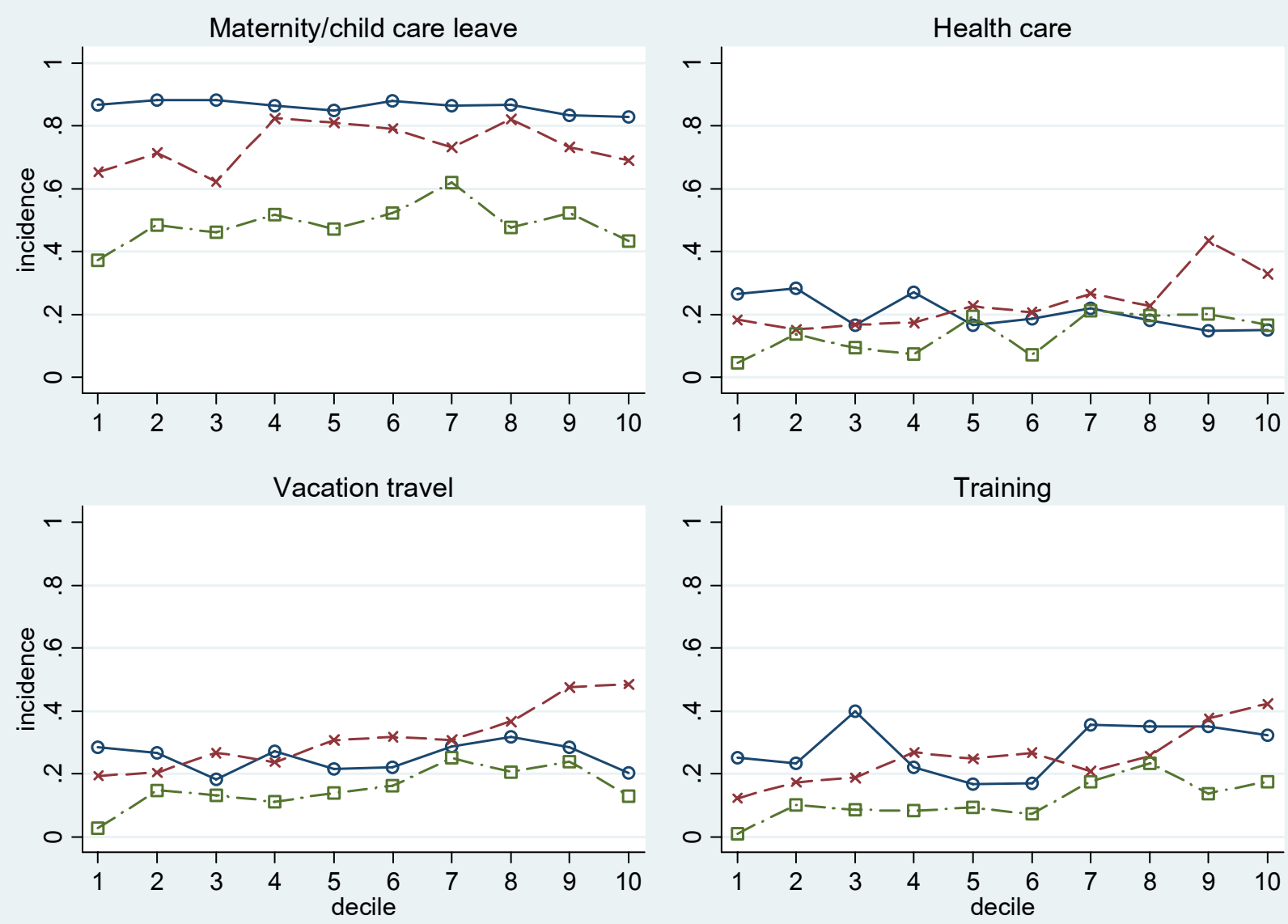

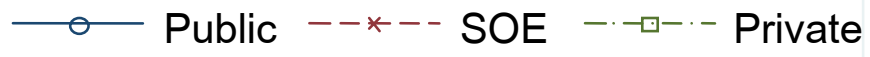


Figure 5: Job Separations by Decile of Conditional Log Wage, 1997-2003

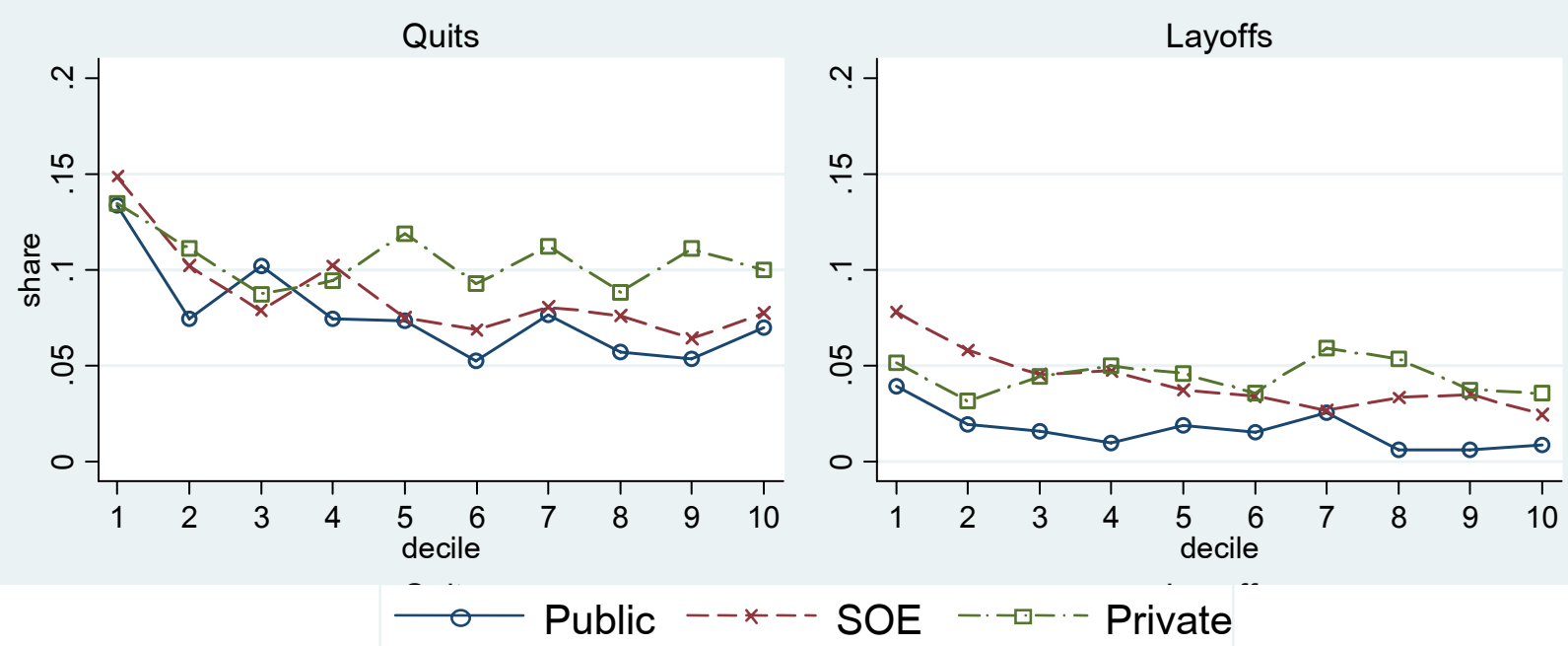




\section{Figure 6: Quantile Estimates of the Private-Public Gap in Expected Wage}
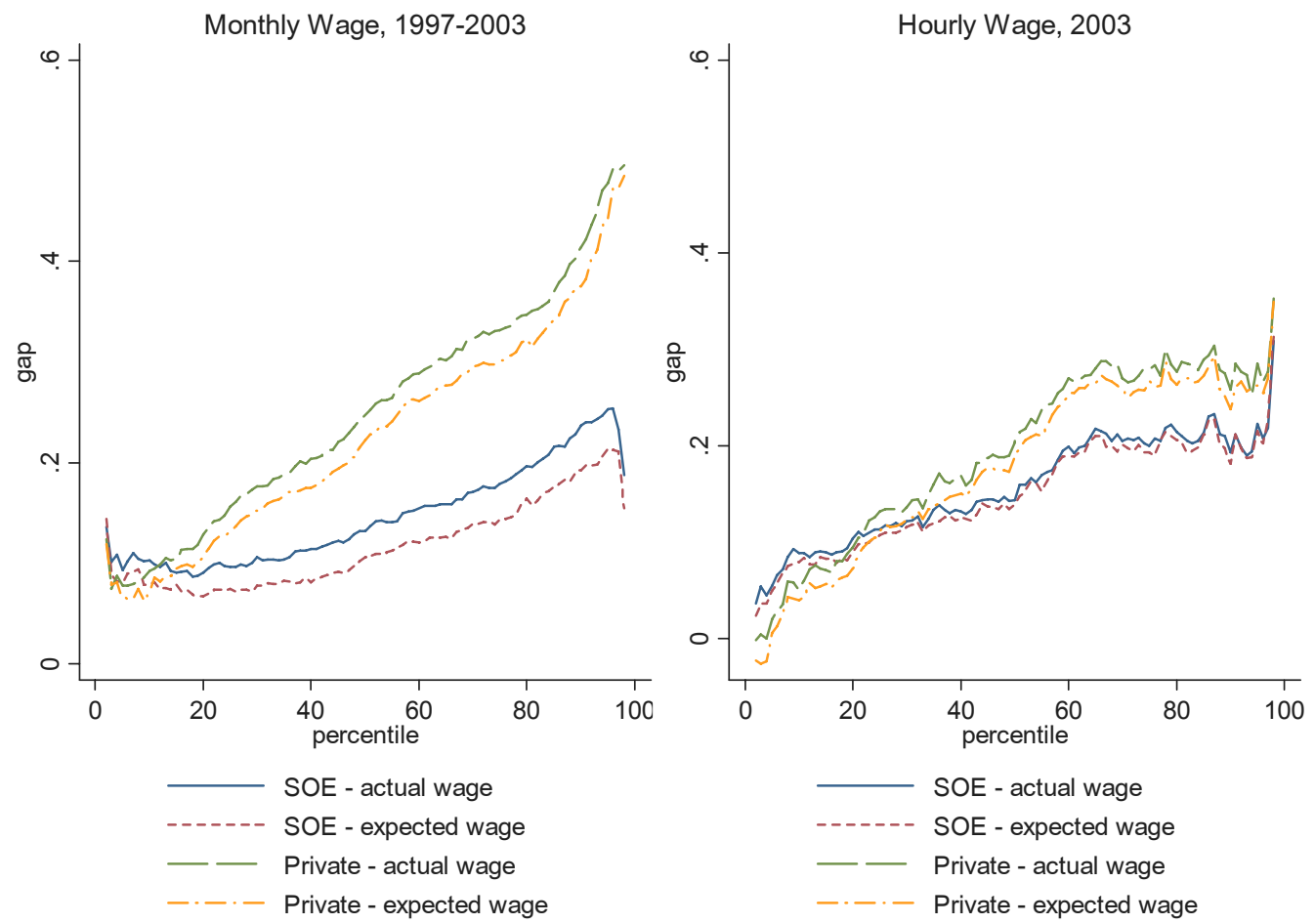

Note: Expected wage is computed as actual wage multiplied by one minus the predicted probability of being fired. 


\section{Appendix Table A1: Definitions of Variables}

\begin{tabular}{|c|c|}
\hline Variable & Description \\
\hline Public & $=1$ if primary employer is a budgetary organization \\
\hline SOE & $=1$ if primary employer is a state enterprise or a local municipal enterprise \\
\hline Private & $\begin{array}{l}=1 \text { if primary employer is a privatized enterprise, a newly established private } \\
\text { enterprise; or a foreign company }\end{array}$ \\
\hline Wage & $\begin{array}{l}\text { Monthly contractual wage after taxes at the primary job in December of the } \\
\text { corresponding year. All wages are converted into hryvnyas. }\end{array}$ \\
\hline $\begin{array}{l}\text { Adjusted years of } \\
\text { schooling }\end{array}$ & $\begin{array}{l}\text { Education status from the survey has been converted into a continuous variable } \\
\text { representing adjusted years of schooling. Adjusted years of schooling were taken as } 4 \\
\text { for } 1-6 \text { grades, } 8 \text { for } 7-9 \text { grades, } 10 \text { for } 10-12 \text { secondary school grades, } 9 \text { for a } \\
\text { vocational non-secondary school diploma, } 11.5 \text { for a vocational secondary school } \\
\text { diploma, } 13 \text { for a technical school diploma and incomplete higher education, } 14 \text { for a } \\
\text { bachelor degree, } 15 \text { for a diploma of specialist, } 16 \text { for a master degree, and } 18 \text { for a } \\
\text { Ph.D. degree. Same definitions are used to compute adjusted years of schooling of } \\
\text { parents. }\end{array}$ \\
\hline Experience & Age minus years of schooling minus 6 \\
\hline Tenure & Number of years since an individual started the primary job \\
\hline Full-time job & $=1$ if worked full time throughout a given year \\
\hline $\begin{array}{l}\text { Weekly hours of } \\
\text { work }\end{array}$ & $\begin{array}{l}\text { 2003: hours per week an individual usually works at the primary job; not available for } \\
\text { other years }\end{array}$ \\
\hline Firm size & $\begin{array}{l}\text { Number of persons working at enterprise (workplace for self-employed) of primary } \\
\text { job: } 1-9,10-49,50-99,100-499,500-999,1000+\text {, and no information. }\end{array}$ \\
\hline Regions & 5 regional dummies: Eastern, Southern, Western, Central and Northern, and Kyiv city \\
\hline Parents' occupation & 10 occupational categories, 1 -digit ISCO- 88 \\
\hline Marital status & $=1$ if married \\
\hline Number of children & Number of children less than 18 years old \\
\hline Union & 2003: $=1$ if belongs to a trade union at the primary job; not available for other years \\
\hline Fringe benefits & $\begin{array}{l}\text { 2003: } 14 \text { categorical variables for various types of fringe benefits at the primary job; } \\
\text { not available for other years }\end{array}$ \\
\hline Bonuses & $\begin{array}{l}\text { Several dummies indicating whether an employee received the following types of } \\
\text { bonuses last year: } 13^{\text {th }} \text { salary, performance-based bonus, bonus for work conditions, } \\
\text { profit sharing, or other bonuses }\end{array}$ \\
\hline Job separations & Two dummies indicating whether an individual is laid off or quit during the next year \\
\hline Job satisfaction & Categorical variable that ranges from 1 (fully unsatisfied) to 5 (fully satisfied) \\
\hline Secondary job & $=1$ if had a secondary job during the reference week \\
\hline Total earnings & $\begin{array}{l}\text { After tax total earnings in the form of money, goods, and services received last month } \\
\text { by all household members from their primary and secondary jobs }\end{array}$ \\
\hline Household income & $\begin{array}{l}\text { After tax sum of contractual labor earnings from all jobs, accrued pensions, and other } \\
\text { types of income actually received last month (stipends, alimonies, unemployment } \\
\text { insurance, child care subsidies, income from capital investment, rental income, etc.) }\end{array}$ \\
\hline Non-durables & $\begin{array}{l}\text { Last month expenditures on food, beverages, tobacco, apparel, and services (including } \\
\text { transportation, health care, education, and entertainment); all weekly food expenses are } \\
\text { multiplied by } 4\end{array}$ \\
\hline Durables & $\begin{array}{l}\text { Last year expenditures on furniture, refrigerator, washer/dryer, car, truck, motorcycle, } \\
\text { summer house, plot, and house/apartment }\end{array}$ \\
\hline Assets & $\begin{array}{l}\text { Four dummy variables indicating whether a household possesses a car, a phone, a cell } \\
\text { phone, or a computer }\end{array}$ \\
\hline Value of housing & Self-estimated current market value of housing \\
\hline Debt for utilities & Amount of accumulated unpaid bills for utilities \\
\hline Housing space & Total area of the residence, $\mathrm{sq} \mathrm{m}$ \\
\hline
\end{tabular}


Table A2: The Share of Total Employment by Sector and Gender

\begin{tabular}{lcccccccc}
\hline & $\mathbf{1 9 9 1}$ & $\mathbf{1 9 9 7}$ & $\mathbf{1 9 9 8}$ & $\mathbf{1 9 9 9}$ & $\mathbf{2 0 0 0}$ & $\mathbf{2 0 0 1}$ & $\mathbf{2 0 0 2}$ & $\mathbf{2 0 0 3}$ \\
\hline & & & & All workers & & & & \\
Public & 0.191 & 0.209 & 0.211 & 0.211 & 0.211 & 0.213 & 0.215 & 0.218 \\
SOE & 0.796 & 0.535 & 0.494 & 0.461 & 0.416 & 0.385 & 0.366 & 0.368 \\
Private & 0.013 & 0.256 & 0.296 & 0.328 & 0.373 & 0.402 & 0.419 & 0.414 \\
N & 2893 & 2452 & 2320 & 2379 & 2453 & 2556 & 2793 & 2786 \\
& & & & Males & & & & \\
Public & 0.099 & 0.113 & 0.105 & 0.111 & 0.107 & 0.107 & 0.105 & 0.106 \\
SOE & 0.881 & 0.583 & 0.548 & 0.497 & 0.445 & 0.413 & 0.388 & 0.402 \\
Private & 0.021 & 0.304 & 0.347 & 0.392 & 0.448 & 0.480 & 0.508 & 0.491 \\
& & & & Females & & & & \\
Public & 0.244 & 0.287 & 0.296 & 0.294 & 0.296 & 0.302 & 0.310 & 0.313 \\
SOE & 0.747 & 0.496 & 0.450 & 0.431 & 0.392 & 0.362 & 0.347 & 0.339 \\
Private & 0.009 & 0.217 & 0.255 & 0.275 & 0.312 & 0.336 & 0.343 & 0.348 \\
\hline
\end{tabular}

Note: Sample weights are applied for 1991. 
Table A3: Summary statistics, 2003

\begin{tabular}{|c|c|c|c|c|c|c|}
\hline & \multicolumn{3}{|c|}{ Males } & \multicolumn{3}{|c|}{ Females } \\
\hline & Public & SOE & Private & Public & SOE & Private \\
\hline Schooling (adjusted years) & $\begin{array}{l}14.032 \\
(3.257)\end{array}$ & $\begin{array}{l}12.450 \\
(2.345)\end{array}$ & $\begin{array}{l}12.267 \\
(2.349)\end{array}$ & $\begin{array}{c}13.580 \\
(2.393)\end{array}$ & $\begin{array}{l}12.710 \\
(2.439)\end{array}$ & $\begin{array}{l}12.653 \\
(2.407)\end{array}$ \\
\hline Experience (years) & $\begin{array}{l}21.836 \\
(10.936)\end{array}$ & $\begin{array}{c}21.067 \\
(10.968)\end{array}$ & $\begin{array}{c}19.431 \\
(11.665)\end{array}$ & $\begin{array}{l}21.031 \\
(10.452)\end{array}$ & $\begin{array}{l}23.603 \\
(10.386)\end{array}$ & $\begin{array}{c}19.597 \\
(10.603)\end{array}$ \\
\hline Tenure (years) & $\begin{array}{c}8.971 \\
(8.488)\end{array}$ & $\begin{array}{c}9.825 \\
(9.194)\end{array}$ & $\begin{array}{c}7.359 \\
(8.942)\end{array}$ & $\begin{array}{l}11.571 \\
(9.219)\end{array}$ & $\begin{array}{l}12.515 \\
(10.082)\end{array}$ & $\begin{array}{c}8.183 \\
(9.470)\end{array}$ \\
\hline Average hours per week & $\begin{array}{c}41.130 \\
(10.824)\end{array}$ & $\begin{array}{l}41.810 \\
(8.703)\end{array}$ & $\begin{array}{c}44.198 \\
(10.556)\end{array}$ & $\begin{array}{l}37.495 \\
(9.361)\end{array}$ & $\begin{array}{l}39.234 \\
(9.151)\end{array}$ & $\begin{array}{c}44.839 \\
(13.306)\end{array}$ \\
\hline Full-time job & 0.971 & 0.973 & 0.952 & 0.909 & 0.916 & 0.941 \\
\hline Union participation & 0.738 & 0.808 & 0.476 & 0.919 & 0.859 & 0.468 \\
\hline Firm size (no. of persons) & & & & & & \\
\hline $1-9$ & 0.044 & 0.029 & 0.115 & 0.076 & 0.092 & 0.242 \\
\hline $10-49$ & 0.272 & 0.128 & 0.229 & 0.312 & 0.235 & 0.239 \\
\hline $50-99$ & 0.177 & 0.126 & 0.115 & 0.223 & 0.125 & 0.095 \\
\hline Size is missing & 0.110 & 0.085 & 0.110 & 0.062 & 0.076 & 0.076 \\
\hline $100-499$ & 0.243 & 0.268 & 0.204 & 0.223 & 0.217 & 0.158 \\
\hline $500-999$ & 0.066 & 0.076 & 0.064 & 0.045 & 0.069 & 0.071 \\
\hline $1000+$ & 0.088 & 0.287 & 0.165 & 0.059 & 0.186 & 0.118 \\
\hline Regions - East & 0.243 & 0.408 & 0.377 & 0.282 & 0.362 & 0.387 \\
\hline South & 0.206 & 0.130 & 0.142 & 0.142 & 0.141 & 0.143 \\
\hline West & 0.368 & 0.218 & 0.229 & 0.316 & 0.260 & 0.197 \\
\hline Center \& North & 0.147 & 0.186 & 0.180 & 0.193 & 0.166 & 0.178 \\
\hline Kyiv city & 0.037 & 0.058 & 0.073 & 0.066 & 0.071 & 0.095 \\
\hline $\mathrm{N}$ & 136 & 515 & 629 & 471 & 511 & 524 \\
\hline
\end{tabular}

Note: Standard deviation for continuous variables is in parentheses. 
Table A4: Sensitivity of Private-Public Wage Gap Estimates to Weak Exclusion Restrictions

Panel A: Two-Step Heckman (1979) Method for Selectivity Correction

\begin{tabular}{|c|c|c|c|c|c|c|}
\hline & \multicolumn{3}{|c|}{ SOE-Public } & \multicolumn{3}{|c|}{ Private-Public } \\
\hline & $\begin{array}{c}\text { All } \\
\text { workers }\end{array}$ & Males & Females & $\begin{array}{c}\text { All } \\
\text { workers }\end{array}$ & Males & Females \\
\hline \multicolumn{7}{|c|}{ Time-Varying Exclusion Restrictions, $1997-2003$ pooled data } \\
\hline \multirow{2}{*}{ Age and age squared } & -0.687 & -1.067 & 3.351 & -0.087 & 0.099 & 4.616 \\
\hline & $(0.703)$ & $(0.841)$ & $(4.094)$ & $(0.402)$ & $(0.615)$ & $(3.309)$ \\
\hline \multirow[t]{2}{*}{ Level of education } & $-0.229 * * *$ & $-0.179 * *$ & -0.106 & $-0.133 * *$ & $-0.420 * * *$ & $0.347 * * *$ \\
\hline & $(0.053)$ & $(0.083)$ & $(0.073)$ & $(0.058)$ & $(0.094)$ & $(0.062)$ \\
\hline \multirow[t]{2}{*}{ No. of children ever born } & -10.999 & 0.591 & $-0.664 * *$ & $0.460 * * *$ & $0.412 *$ & $0.708 * * *$ \\
\hline & $(46.104)$ & $(0.666)$ & $(0.334)$ & $(0.121)$ & $(0.239)$ & $(0.177)$ \\
\hline \multirow[t]{2}{*}{ No. of children $<18$ years } & $0.598^{*}$ & $-0.765^{*}$ & $1.457 * *$ & $0.539 * * *$ & -0.021 & $0.891 * * *$ \\
\hline & $(0.360)$ & $(0.461)$ & $(0.648)$ & $(0.179)$ & $(0.248)$ & $(0.296)$ \\
\hline \multirow[t]{3}{*}{ Marital status } & 0.000 & $-2.012 * * *$ & 3.479 & 0.121 & $-0.751 * * *$ & $0.515 * * *$ \\
\hline & $(0.000)$ & $(0.713)$ & $(17.515)$ & $(0.116)$ & $(0.221)$ & $(0.105)$ \\
\hline & Time-Invar & ant Exclusion & Restrictior & 003 data & & \\
\hline \multirow[t]{2}{*}{ Total household income } & 0.946 & -27.822 & $0.781 * *$ & 3.821 & 2.480 & 0.677 \\
\hline & $(0.961)$ & $(689.330)$ & $(0.325)$ & $(6.361)$ & $(2.449)$ & $(0.884)$ \\
\hline \multirow[t]{2}{*}{ Industry in 1991} & $0.308 * * *$ & $0.498 * * *$ & $0.200 * *$ & $0.238 * * *$ & 0.169 & $0.243 * * *$ \\
\hline & $(0.074)$ & $(0.137)$ & $(0.089)$ & $(0.064)$ & $(0.146)$ & $(0.068)$ \\
\hline \multirow{2}{*}{ Parents' occupation } & 0.023 & 0.225 & 0.221 & -0.072 & 0.215 & 0.235 \\
\hline & $(0.140)$ & $(0.161)$ & $(0.140)$ & $(0.213)$ & $(0.232)$ & $(0.188)$ \\
\hline
\end{tabular}

Panel B: Maximum Likelihood Treatment Regression Estimates

\begin{tabular}{lcccccc}
\hline & \multicolumn{3}{c}{ SOE-Public } & \multicolumn{2}{c}{ Private-Public } \\
\cline { 2 - 7 } & $\begin{array}{c}\text { All } \\
\text { workers }\end{array}$ & Males & Females & $\begin{array}{c}\text { All } \\
\text { workers }\end{array}$ & Males & Females \\
\hline \multirow{3}{*}{ Age and age squared } & Time-Varying Exclusion Restrictions, 1997-2003 pooled data & \\
& $-0.246^{* * *}$ & 0.102 & $0.619^{* * *}$ & $-0.399^{* * *}$ & 0.063 & $0.459^{* * *}$ \\
Level of education & $(0.063)$ & $(0.117)$ & $(0.038)$ & $(0.036)$ & $(0.243)$ & $(0.157)$ \\
& $-0.257^{* * *}$ & -0.061 & $-0.376^{* * *}$ & $-0.325^{* * *}$ & $-0.282^{* * *}$ & $0.356^{* * *}$ \\
No. of children ever born & $(0.037)$ & $(0.059)$ & $(0.033)$ & $(0.037)$ & $(0.060)$ & $(0.066)$ \\
& $-0.256^{* * *}$ & 0.144 & $-0.402^{* * *}$ & $0.940^{* * *}$ & $0.810^{* * *}$ & $0.542^{* * *}$ \\
No. of children $<18$ years & $(0.061)$ & $(0.134)$ & $(0.034)$ & $(0.032)$ & $(0.079)$ & $(0.114)$ \\
& $0.728^{* * *}$ & 0.061 & $0.631^{* * *}$ & $0.949^{* * *}$ & 0.018 & $0.514^{* * *}$ \\
Marital status & $(0.027)$ & $(0.102)$ & $(0.036)$ & $(0.032)$ & $(0.158)$ & $(0.141)$ \\
& $-0.050^{* * *}$ & -0.017 & $0.615^{* * *}$ & $-0.393^{* * *}$ & $-0.221^{* * *}$ & $0.478^{* * *}$ \\
Total household income & $(0.011)$ & $(0.090)$ & $(0.040)$ & $(0.038)$ & $(0.086)$ & $(0.087)$ \\
Industry in 1991 & Time-Invariant Exclusion & Restrictions, & 2003 data & & \\
& $0.687^{* * *}$ & 0.174 & $0.508^{* * *}$ & $0.976^{* * *}$ & $0.610^{* * *}$ & $0.840^{* * *}$ \\
Parents' occupation & $(0.087)$ & $(0.365)$ & $(0.104)$ & $(0.070)$ & $(0.231)$ & $(0.106)$ \\
& $0.446^{* * *}$ & $0.524 * * *$ & $0.227^{* *}$ & $0.236^{* * *}$ & 0.180 & $0.246^{* * *}$ \\
& $(0.096)$ & $(0.127)$ & $(0.112)$ & $(0.071)$ & $(0.173)$ & $(0.067)$ \\
& $-0.434^{* * *}$ & 0.242 & $0.484^{* * *}$ & $-0.485^{* * *}$ & 0.451 & $-0.316^{* * *}$ \\
\hline
\end{tabular}

Notes: $\mathrm{N}=2,561$. Reported are the estimated log wage effects of the non-public types of firms relative to public firms from treatment regressions, with alternative exclusion restrictions. Standard errors are in parentheses; * significant at $10 \%$; $* *$ significant at 5\%;*** significant at 1\%. All specifications include years of schooling, a gender dummy, experience, experience squared, tenure, tenure squared, a dummy for full-time job, 7 categories of firm size, and 5 regional groups. 
Table A5: Alternative Measures of Household Expenditures and Wealth, 2003

\begin{tabular}{|c|c|c|c|c|c|c|c|c|c|}
\hline & \multirow[b]{2}{*}{ Food } & \multirow[b]{2}{*}{ Apparel } & \multirow[b]{2}{*}{ Services } & \multirow[b]{2}{*}{$\begin{array}{c}\text { Non- } \\
\text { durables } \\
\text { less food }\end{array}$} & \multirow[b]{2}{*}{$\begin{array}{l}\text { Debt for } \\
\text { utilities }\end{array}$} & \multicolumn{4}{|c|}{ In household current possession } \\
\hline & & & & & & Computer & Phone & Cell & Car \\
\hline Mean (depvar) & 87.9 & 185.8 & 190.9 & 287.9 & 776.3 & 0.073 & 0.528 & 0.090 & 0.237 \\
\hline St.dev.(depvar) & 82.8 & 200.8 & 600.2 & 634.1 & 1169.6 & 0.261 & 0.499 & 0.286 & 0.425 \\
\hline $\mathrm{N}$ & 2066 & 1184 & 2034 & 2066 & 2223 & 2264 & 2269 & 2263 & 2269 \\
\hline Units & UAH & UAH & UAH & UAH & UAH & share & share & share & share \\
\hline \multirow[t]{2}{*}{ Reference period } & week & month & month & month & stock & stock & stock & stock & stock \\
\hline & (1) OLS & (2) OLS & (3) OLS & (4) OLS & (5) Tobit & (6) Probit & (7) Probit & (8) Probit & (9) Probit \\
\hline \multicolumn{10}{|l|}{ No. of HH earners in } \\
\hline \multirow[t]{2}{*}{ SOE } & 0.026 & 0.053 & 0.003 & 0.011 & 0.266 & 0.003 & -0.027 & 0.005 & -0.031 \\
\hline & $(0.036)$ & $(0.060)$ & $(0.052)$ & $(0.052)$ & $(0.392)$ & $(0.009)$ & $(0.024)$ & $(0.012)$ & $(0.019)$ \\
\hline \multirow[t]{2}{*}{ Private sector } & 0.050 & 0.027 & 0.055 & 0.066 & 0.668 & $0.019 * *$ & -0.017 & 0.014 & -0.027 \\
\hline & $(0.038)$ & $(0.063)$ & $(0.055)$ & $(0.055)$ & $(0.409)$ & $(0.010)$ & $(0.025)$ & $(0.012)$ & $(0.020)$ \\
\hline \multirow[t]{2}{*}{ Other sectors } & $-0.170 * * *$ & $-0.229 * *$ & -0.133 & $-0.180 * *$ & 0.922 & 0.008 & $-0.106 * * *$ & 0.011 & -0.039 \\
\hline & $(0.060)$ & $(0.109)$ & $(0.089)$ & $(0.089)$ & $(0.660)$ & $(0.017)$ & $(0.040)$ & $(0.020)$ & $(0.032)$ \\
\hline \multirow[t]{2}{*}{ No. of HH earners } & $0.073 *$ & -0.007 & $0.119 * *$ & $0.127 * *$ & -0.263 & -0.003 & 0.035 & -0.008 & 0.014 \\
\hline & $(0.038)$ & $(0.063)$ & $(0.055)$ & $(0.055)$ & $(0.412)$ & $(0.009)$ & $(0.025)$ & $(0.013)$ & $(0.020)$ \\
\hline \multirow[t]{2}{*}{ No. of HH members } & $0.112 * * *$ & $0.117 * * *$ & $0.199 * * *$ & $0.177 * * *$ & $0.650 * * *$ & $0.015 * * *$ & $0.040 * * *$ & 0.006 & $0.063 * * *$ \\
\hline & $(0.017)$ & $(0.030)$ & $(0.024)$ & $(0.024)$ & $(0.177)$ & $(0.004)$ & $(0.012)$ & $(0.005)$ & $(0.009)$ \\
\hline \multirow{2}{*}{$\begin{array}{c}\text { Average schooling } \\
\text { of } \mathrm{HH} \text { earners }\end{array}$} & $0.028 * * *$ & $0.025 * *$ & $0.066 * * *$ & $0.061 * * *$ & 0.094 & $0.017 * * *$ & $0.056 * * *$ & $0.014 * * *$ & $0.024 * * *$ \\
\hline & $(0.007)$ & $(0.013)$ & $(0.010)$ & $(0.010)$ & $(0.078)$ & $(0.002)$ & $(0.006)$ & $(0.002)$ & $(0.004)$ \\
\hline Share of males among & $0.075^{*}$ & 0.031 & 0.030 & 0.029 & $-1.911 * * *$ & -0.007 & $-0.078 * * *$ & -0.008 & $0.083 * * *$ \\
\hline HH earners & $(0.040)$ & $(0.072)$ & $(0.059)$ & $(0.059)$ & $(0.445)$ & $(0.011)$ & $(0.028)$ & $(0.013)$ & $(0.022)$ \\
\hline $\mathrm{N}$ & 2066 & 1184 & 2034 & 2066 & $2223[736]$ & 2264 & 2269 & 2263 & 2269 \\
\hline
\end{tabular}

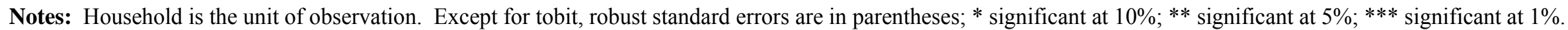

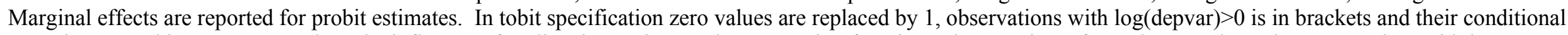
mean is reported in row 1. To reduce the influence of outliers in earnings and consumption functions, the OLS is performed as a Huber robust regression, with lower weights given to influential observations. All expenditures measures are used in logarithmic form. HH denotes household. UAH is Ukrainian currency. All

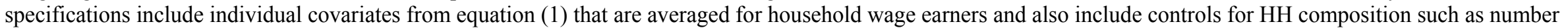
of $\mathrm{HH}$ members, number of children, and number of retirees. 
Table A6: Household Income, Expenditures, and Wealth, Head of Household Specification, 2003

\begin{tabular}{|c|c|c|c|c|c|c|c|c|c|}
\hline & $\begin{array}{c}\begin{array}{c}\text { Contractual } \\
\text { wage }\end{array} \\
\text { (1) OLS } \\
\end{array}$ & $\begin{array}{c}\begin{array}{c}\text { Actual } \\
\text { wage }\end{array} \\
\text { (2) OLS } \\
\end{array}$ & $\begin{array}{c}\begin{array}{c}\text { Total } \\
\text { earnings }\end{array} \\
\text { (3) OLS } \\
\end{array}$ & $\begin{array}{c}\text { HH } \\
\text { income }\end{array}$ & $\begin{array}{c}\begin{array}{c}\text { Non- } \\
\text { durables }\end{array} \\
\text { (5) OLS } \\
\end{array}$ & $\begin{array}{l}\text { Durables } \\
\text { (6) Tobit } \\
\end{array}$ & $\begin{array}{c}\begin{array}{l}\text { Value of } \\
\text { housing }\end{array} \\
\text { (7) Tobit } \\
\end{array}$ & $\begin{array}{c}\begin{array}{c}\text { Housing } \\
\text { space }\end{array} \\
\text { (8) OLS } \\
\end{array}$ & $\begin{array}{l}\text { C-Y gap } \\
\text { (9) OLS } \\
\end{array}$ \\
\hline \multicolumn{10}{|l|}{ HH head employed in } \\
\hline SOE & $\begin{array}{l}0.185 * * * \\
(0.030)\end{array}$ & $\begin{array}{l}0.159 * * * \\
(0.032)\end{array}$ & $\begin{array}{l}0.167 * * * \\
(0.040)\end{array}$ & $\begin{array}{l}0.153 * * * \\
(0.028)\end{array}$ & $\begin{array}{c}0.002 \\
(0.049)\end{array}$ & $\begin{array}{l}-0.207 \\
(1.308)\end{array}$ & $\begin{array}{l}-0.660 * \\
(0.338)\end{array}$ & $\begin{array}{l}-1.983 \\
(1.462)\end{array}$ & $\begin{array}{l}-0.112 * * \\
(0.048)\end{array}$ \\
\hline Private sector & $\begin{array}{l}0.238 * * * \\
(0.030)\end{array}$ & $\begin{array}{l}0.233 * * * \\
(0.032)\end{array}$ & $\begin{array}{l}0.217 * * * \\
(0.041)\end{array}$ & $\begin{array}{l}0.176 * * * \\
(0.029)\end{array}$ & $\begin{array}{c}0.044 \\
(0.049)\end{array}$ & $\begin{array}{l}-0.237 \\
(1.317)\end{array}$ & $\begin{array}{l}-0.465 \\
(0.331)\end{array}$ & $\begin{array}{l}-0.539 \\
(1.459)\end{array}$ & $\begin{array}{l}-0.118 * * \\
(0.048)\end{array}$ \\
\hline Other sectors & $\begin{array}{c}0.017 \\
(0.047)\end{array}$ & $\begin{array}{c}0.025 \\
(0.053)\end{array}$ & $\begin{array}{l}-0.047 \\
(0.068)\end{array}$ & $\begin{array}{c}0.038 \\
(0.045)\end{array}$ & $\begin{array}{c}-0.259 * * * \\
(0.077)\end{array}$ & $\begin{array}{c}1.755 \\
(1.977)\end{array}$ & $\begin{array}{l}-0.306 \\
(0.541)\end{array}$ & $\begin{array}{c}2.625 \\
(2.367)\end{array}$ & $\begin{array}{c}-0.257 * * * \\
(0.074)\end{array}$ \\
\hline No. of $\mathrm{HH}$ earners & $\begin{array}{l}0.567 * * * \\
(0.016)\end{array}$ & $\begin{array}{l}0.540 * * * \\
(0.018)\end{array}$ & $\begin{array}{l}0.344 * * * \\
(0.022)\end{array}$ & $\begin{array}{l}0.466 * * * \\
(0.017)\end{array}$ & $\begin{array}{l}0.084 * * * \\
(0.029)\end{array}$ & $\begin{array}{l}-1.339 * \\
(0.784)\end{array}$ & $\begin{array}{c}0.181 \\
(0.199)\end{array}$ & $\begin{array}{l}-1.353 \\
(0.858)\end{array}$ & $\begin{array}{c}-0.374 * * * \\
(0.028)\end{array}$ \\
\hline No. of HH members & $\ldots$ & $\ldots$ & $\ldots$ & $\begin{array}{l}-0.009 \\
(0.010)\end{array}$ & $\begin{array}{l}0.143^{* * * *} \\
(0.017)\end{array}$ & $\begin{array}{l}-0.029 \\
(0.442)\end{array}$ & $\begin{array}{l}0.266^{* *} \\
(0.120)\end{array}$ & $\begin{array}{l}6.384 * * * \\
(0.502)\end{array}$ & $\begin{array}{l}0.140 * * * \\
(0.016)\end{array}$ \\
\hline HH head schooling & $\begin{array}{l}0.045 * * * \\
(0.004)\end{array}$ & $\begin{array}{l}0.044 * * * \\
(0.004)\end{array}$ & $\begin{array}{l}0.049 * * * \\
(0.006)\end{array}$ & $\begin{array}{l}0.036 * * * \\
(0.004)\end{array}$ & $\begin{array}{l}0.032 * * * \\
(0.007)\end{array}$ & $\begin{array}{c}0.282 \\
(0.181)\end{array}$ & $\begin{array}{l}0.158 * * * \\
(0.047)\end{array}$ & $\begin{array}{c}0.312 \\
(0.200)\end{array}$ & $\begin{array}{l}-0.002 \\
(0.006)\end{array}$ \\
\hline HH head male & $\begin{array}{l}0.227 * * * \\
(0.021)\end{array}$ & $\begin{array}{l}0.236 * * * \\
(0.023)\end{array}$ & $\begin{array}{l}0.109 * * * \\
(0.030)\end{array}$ & $\begin{array}{l}0.176^{* * *} \\
(0.021)\end{array}$ & $\begin{array}{c}0.057 \\
(0.035)\end{array}$ & $\begin{array}{c}1.166 \\
(0.949)\end{array}$ & $\begin{array}{c}0.070 \\
(0.247)\end{array}$ & $\begin{array}{c}1.571 \\
(1.066)\end{array}$ & $\begin{array}{c}-0.134 * * * \\
(0.034)\end{array}$ \\
\hline $\mathrm{N}$ & 2259 & 2167 & 2068 & 2189 & 1989 & 2221 & 1330 & 2034 & 1938 \\
\hline
\end{tabular}

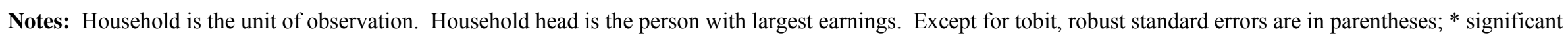

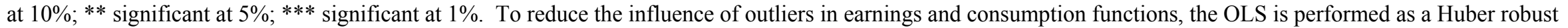
regression, with lower weights given to influential observations. All income and expenditures measures are used in logarithmic form. HH denotes household. All specifications include individual covariates from equation (1) that are pertinent to the $\mathrm{HH}$ head. Specifications related to the whole household (as opposed to wage earners) also include controls for $\mathrm{HH}$ composition such as number of $\mathrm{HH}$ members, number of children, and number of retirees (specifications 4 through 9). The consumption-income gap (C-Y gap) is defined in the text. 
Table A7: Alternative Measures of Household Expenditures and Wealth, Head of Household Specification, 2003

\begin{tabular}{|c|c|c|c|c|c|c|c|c|c|}
\hline & \multirow[b]{2}{*}{ Food } & \multirow[b]{2}{*}{ Apparel } & \multirow[b]{2}{*}{ Services } & \multirow[b]{2}{*}{$\begin{array}{c}\text { Non- } \\
\text { durables } \\
\text { less food }\end{array}$} & \multirow[b]{2}{*}{$\begin{array}{c}\text { Debt for } \\
\text { utilities }\end{array}$} & \multicolumn{4}{|c|}{ In household current possession } \\
\hline & & & & & & Computer & Phone & Cell & Car \\
\hline & OLS & OLS & OLS & OLS & Tobit & Probit & Probit & Probit & Probit \\
\hline \multicolumn{10}{|l|}{ HH head employed in } \\
\hline \multirow[t]{2}{*}{$\mathrm{SOE}$} & 0.023 & 0.087 & -0.031 & -0.009 & -0.036 & 0.002 & -0.039 & 0.015 & $-0.051 * *$ \\
\hline & $(0.049)$ & $(0.085)$ & $(0.071)$ & $(0.071)$ & $(0.534)$ & $(0.014)$ & $(0.033)$ & $(0.017)$ & $(0.026)$ \\
\hline \multirow[t]{2}{*}{ Private sector } & 0.039 & 0.050 & 0.033 & 0.069 & 0.244 & 0.016 & -0.023 & 0.025 & -0.029 \\
\hline & $(0.049)$ & $(0.085)$ & $(0.071)$ & $(0.072)$ & $(0.533)$ & $(0.014)$ & $(0.033)$ & $(0.017)$ & $(0.026)$ \\
\hline \multirow[t]{2}{*}{ Other sectors } & $-0.254 * * *$ & $-0.247 *$ & $-0.217^{*}$ & $-0.193 *$ & 0.796 & -0.010 & $-0.123 * *$ & 0.029 & -0.029 \\
\hline & $(0.077)$ & $(0.142)$ & $(0.114)$ & $(0.115)$ & $(0.832)$ & $(0.020)$ & $(0.051)$ & $(0.031)$ & $(0.038)$ \\
\hline \multirow[t]{2}{*}{ No. of HH earners } & $0.062 * *$ & 0.003 & $0.119 * * *$ & $0.133 * * *$ & 0.326 & 0.002 & 0.020 & -0.003 & -0.021 \\
\hline & $(0.029)$ & $(0.048)$ & $(0.042)$ & $(0.042)$ & $(0.305)$ & $(0.007)$ & $(0.019)$ & $(0.009)$ & $(0.015)$ \\
\hline \multirow[t]{2}{*}{ No. of HH members } & $0.114 * * *$ & $0.115 * * *$ & $0.205 * * *$ & $0.182 * * *$ & $0.677 * * *$ & $0.015 * * *$ & $0.038 * * *$ & 0.007 & $0.062 * * *$ \\
\hline & $(0.017)$ & $(0.030)$ & $(0.024)$ & $(0.024)$ & $(0.177)$ & $(0.004)$ & $(0.011)$ & $(0.005)$ & $(0.009)$ \\
\hline \multirow[t]{2}{*}{ HH head schooling } & $0.024 * * *$ & $0.025 * *$ & $0.053 * * *$ & $0.049 * * *$ & 0.067 & $0.015 * * *$ & $0.052 * * *$ & $0.013 * * *$ & $0.022 * * *$ \\
\hline & $(0.007)$ & $(0.012)$ & $(0.010)$ & $(0.010)$ & $(0.073)$ & $(0.002)$ & $(0.005)$ & $(0.002)$ & $(0.004)$ \\
\hline \multirow[t]{2}{*}{ HH head male } & $0.126 * * *$ & 0.034 & 0.031 & 0.036 & $-1.398 * * *$ & -0.003 & $-0.056 * *$ & -0.006 & $0.068 * * *$ \\
\hline & $(0.035)$ & $(0.062)$ & $(0.052)$ & $(0.052)$ & $(0.384)$ & $(0.010)$ & $(0.024)$ & $(0.011)$ & $(0.019)$ \\
\hline $\mathrm{N}$ & 2054 & 1178 & 2022 & 2055 & 2210 & 2251 & 2256 & 2250 & 2256 \\
\hline
\end{tabular}

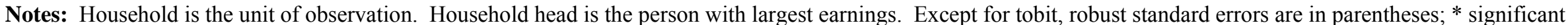
at $10 \%$; ** significant at 5\%; *** significant at 1\%. Marginal effects are reported for probit estimates. To reduce the influence of outliers in earnings and consumption functions, the OLS is performed as a Huber robust regression, with lower weights given to influential observations. All expenditures measures are used in logarithmic form. HH denotes household. All specifications include individual covariates for the $\mathrm{HH}$ head from equation (1) and also include controls for HH composition such as number of $\mathrm{HH}$ members, number of children, and number of retirees. 
Table A8: Household Expenditure and Wealth Functions: Testing the Elite Hypothesis

\begin{tabular}{|c|c|c|c|c|c|c|}
\hline & $\begin{array}{c}\text { Non- } \\
\text { durables } \\
\text { less food }\end{array}$ & $\begin{array}{c}\text { Non- } \\
\text { durables }\end{array}$ & $\begin{array}{l}\text { Value of } \\
\text { housing }\end{array}$ & $\begin{array}{l}\text { Housing } \\
\text { space }\end{array}$ & Car & C-Y gap \\
\hline & (1) OLS & (2) OLS & (3) Tobit & (4) OLS & (5) Probit & (6) OLS \\
\hline \multicolumn{7}{|l|}{ No. of $\mathrm{HH}$ earners in } \\
\hline SOE & $\begin{array}{c}0.008 \\
(0.052)\end{array}$ & $\begin{array}{c}0.018 \\
(0.036)\end{array}$ & $\begin{array}{l}-0.643 * * * \\
(0.244)\end{array}$ & $\begin{array}{l}-2.515^{* *} \\
(1.074)\end{array}$ & $\begin{array}{l}-0.035^{*} \\
(0.019)\end{array}$ & $\begin{array}{l}-0.073 * * \\
(0.035)\end{array}$ \\
\hline Private sector & $\begin{array}{c}0.061 \\
(0.055)\end{array}$ & $\begin{array}{c}0.058 \\
(0.038)\end{array}$ & $\begin{array}{l}-0.378 \\
(0.251)\end{array}$ & $\begin{array}{l}-0.696 \\
(1.123)\end{array}$ & $\begin{array}{l}-0.031 \\
(0.020)\end{array}$ & $\begin{array}{l}-0.074 * * \\
(0.037)\end{array}$ \\
\hline Other sectors & $\begin{array}{l}-0.179 * * \\
(0.089)\end{array}$ & $\begin{array}{l}-0.174 * * * \\
(0.060)\end{array}$ & $\begin{array}{l}-0.081 \\
(0.415)\end{array}$ & $\begin{array}{c}1.164 \\
(1.861)\end{array}$ & $\begin{array}{l}-0.038 \\
(0.032)\end{array}$ & $\begin{array}{l}-0.171 * * * \\
(0.058)\end{array}$ \\
\hline No. of HH earners & $\begin{array}{l}0.117^{* *} \\
(0.055)\end{array}$ & $\begin{array}{l}0.077 * * \\
(0.038)\end{array}$ & $\begin{array}{r}0.466^{*} \\
(0.256)\end{array}$ & $\begin{array}{l}-0.398 \\
(1.133)\end{array}$ & $\begin{array}{c}0.012 \\
(0.020)\end{array}$ & $\begin{array}{l}-0.338 * * * \\
(0.037)\end{array}$ \\
\hline No. of HH members & $\begin{array}{l}0.178^{* * * *} \\
(0.025)\end{array}$ & $\begin{array}{l}0.137 * * * \\
(0.017)\end{array}$ & $\begin{array}{l}0.280^{* *} \\
(0.120)\end{array}$ & $\begin{array}{l}6.202 * * * \\
(0.508)\end{array}$ & $\begin{array}{l}0.062 * * * \\
(0.009)\end{array}$ & $\begin{array}{l}0.143^{* * *} \\
(0.017)\end{array}$ \\
\hline $\begin{array}{l}\text { Average schooling } \\
\text { of HH earners }\end{array}$ & $\begin{array}{l}0.055^{* * *} \\
(0.011)\end{array}$ & $\begin{array}{l}0.035^{* * *} \\
(0.007)\end{array}$ & $\begin{array}{l}0.156^{* * *} \\
(0.052)\end{array}$ & $\begin{array}{r}0.412^{*} \\
(0.223)\end{array}$ & $\begin{array}{l}0.024 * * * \\
(0.004)\end{array}$ & $\begin{array}{l}-0.001 \\
(0.007)\end{array}$ \\
\hline $\begin{array}{l}\text { Share of males among } \\
\text { HH earners }\end{array}$ & $\begin{array}{c}0.003 \\
(0.059)\end{array}$ & $\begin{array}{c}0.008 \\
(0.041)\end{array}$ & $\begin{array}{l}-0.045 \\
(0.286)\end{array}$ & $\begin{array}{c}2.412^{*} \\
(1.240)\end{array}$ & $\begin{array}{l}0.077 * * * \\
(0.023)\end{array}$ & $\begin{array}{l}-0.154 * * * \\
(0.040)\end{array}$ \\
\hline $\begin{array}{l}\text { Household earnings } \\
\text { in } 1991\end{array}$ & $\begin{array}{l}0.102 * * \\
(0.044)\end{array}$ & $\begin{array}{l}0.103 * * * \\
(0.031)\end{array}$ & $\begin{array}{c}0.195 \\
(0.207)\end{array}$ & $\begin{array}{c}0.938 \\
(0.899)\end{array}$ & $\begin{array}{l}0.043 * * * \\
(0.016)\end{array}$ & $\begin{array}{l}-0.008 \\
(0.030)\end{array}$ \\
\hline Father-manager & $\begin{array}{l}0.323^{* *} \\
(0.129)\end{array}$ & $\begin{array}{l}0.182^{* *} \\
(0.092)\end{array}$ & $\begin{array}{c}0.885 \\
(0.585)\end{array}$ & $\begin{array}{l}-2.205 \\
(2.611)\end{array}$ & $\begin{array}{l}0.146^{* *} \\
(0.057)\end{array}$ & $\begin{array}{c}0.063 \\
(0.093)\end{array}$ \\
\hline Father-professional & $\begin{array}{c}0.022 \\
(0.094)\end{array}$ & $\begin{array}{c}0.001 \\
(0.065)\end{array}$ & $\begin{array}{c}0.837^{*} \\
(0.451)\end{array}$ & $\begin{array}{c}0.226 \\
(1.973)\end{array}$ & $\begin{array}{c}0.000 \\
(0.036)\end{array}$ & $\begin{array}{l}-0.011 \\
(0.064)\end{array}$ \\
\hline Mother-manager & $\begin{array}{c}0.051 \\
(0.206)\end{array}$ & $\begin{array}{l}-0.010 \\
(0.156)\end{array}$ & $\begin{array}{c}1.179 \\
(1.072)\end{array}$ & $\begin{array}{c}1.144 \\
(4.436)\end{array}$ & $\begin{array}{l}-0.023 \\
(0.077)\end{array}$ & $\begin{array}{l}-0.051 \\
(0.153)\end{array}$ \\
\hline Mother-professional & $\begin{array}{c}0.019 \\
(0.086)\end{array}$ & $\begin{array}{c}0.006 \\
(0.060)\end{array}$ & $\begin{array}{l}-0.067 \\
(0.403)\end{array}$ & $\begin{array}{c}0.034 \\
(1.833)\end{array}$ & $\begin{array}{l}-0.042 \\
(0.030)\end{array}$ & $\begin{array}{l}-0.060 \\
(0.059)\end{array}$ \\
\hline $\mathrm{N}$ & 2066 & 2000 & 1337 & 2047 & 2269 & 1949 \\
\hline
\end{tabular}

Notes: Household is the unit of observation. Except for tobit, robust standard errors are in parentheses; ${ }^{*}$ significant at $10 \%$;* significant at $5 \%$; *** significant at $1 \%$. To reduce the influence of outliers in earnings and consumption functions, the OLS is performed as a Huber robust regression, with lower weights given to influential observations. All expenditures measures are used in logarithmic form. HH denotes household. All specifications include individual covariates from equation (1) that are averaged for household wage earners and also include controls for HH composition such as number of $\mathrm{HH}$ members, number of children, and number of retirees. The consumption-income gap (C-Y gap) is defined in the text. 
Table A9: Sectoral Choice Model, MNL, 1997-2003

\begin{tabular}{|c|c|c|c|c|}
\hline & $\begin{array}{c}\text { SOE vs. } \\
\text { Public }\end{array}$ & $\begin{array}{c}\text { Private vs. } \\
\text { Public } \\
\end{array}$ & $\begin{array}{c}\text { SOE vs. } \\
\text { Public }\end{array}$ & $\begin{array}{c}\text { Private vs. } \\
\text { Public } \\
\end{array}$ \\
\hline Schooling (years) & $\begin{array}{l}-0.165 * * * \\
(0.007)\end{array}$ & $\begin{array}{l}-0.184 * * * \\
(0.007)\end{array}$ & $\begin{array}{l}-0.159 * * * \\
(0.008)\end{array}$ & $\begin{array}{l}-0.182 * * * \\
(0.008)\end{array}$ \\
\hline Female & $\begin{array}{l}-1.133^{* * *} \\
(0.036)\end{array}$ & $\begin{array}{l}-1.200^{* * * *} \\
(0.036)\end{array}$ & $\begin{array}{l}-1.131 * * * \\
(0.042)\end{array}$ & $\begin{array}{l}-1.239 * * * \\
(0.043)\end{array}$ \\
\hline Married & $\begin{array}{l}-0.117^{* * * *} \\
(0.043)\end{array}$ & $\begin{array}{l}-0.453^{* * * *} \\
(0.042)\end{array}$ & $\begin{array}{l}-0.099 * * \\
(0.050)\end{array}$ & $\begin{array}{l}-0.441 * * * \\
(0.050)\end{array}$ \\
\hline No. of children $<18$ years & $\begin{array}{l}-0.048^{* *} \\
(0.021)\end{array}$ & $\begin{array}{l}-0.059 * * * \\
(0.021)\end{array}$ & $\begin{array}{l}-0.066^{* * *} \\
(0.025)\end{array}$ & $\begin{array}{l}-0.097 * * * \\
(0.025)\end{array}$ \\
\hline Experience (years) & $\begin{array}{c}0.002 \\
(0.002)\end{array}$ & $\begin{array}{l}-0.023 * * * \\
(0.002)\end{array}$ & $\begin{array}{c}0.001 \\
(0.002)\end{array}$ & $\begin{array}{l}-0.026 * * * \\
(0.002)\end{array}$ \\
\hline Mother's occupation & & & & \\
\hline Managers & $\begin{array}{l}-0.389 * * \\
(0.178)\end{array}$ & $\begin{array}{l}-0.158 \\
(0.172)\end{array}$ & $\begin{array}{l}-0.290 \\
(0.211)\end{array}$ & $\begin{array}{l}-0.171 \\
(0.204)\end{array}$ \\
\hline Professionals & $\begin{array}{l}-0.376^{* * * *} \\
(0.072)\end{array}$ & $\begin{array}{l}-0.421 * * * \\
(0.071)\end{array}$ & $\begin{array}{l}-0.296 * * * \\
(0.085)\end{array}$ & $\begin{array}{l}-0.362 * * * \\
(0.084)\end{array}$ \\
\hline Associate professionals & $\begin{array}{l}-0.357 * * * \\
(0.062)\end{array}$ & $\begin{array}{l}-0.163 * * * \\
(0.062)\end{array}$ & $\begin{array}{l}-0.348^{* * * *} \\
(0.073)\end{array}$ & $\begin{array}{l}-0.137^{*} \\
(0.073)\end{array}$ \\
\hline Clerks & $\begin{array}{l}-0.289 * * * \\
(0.073)\end{array}$ & $\begin{array}{l}-0.114 \\
(0.073)\end{array}$ & $\begin{array}{l}-0.276^{* * * *} \\
(0.085)\end{array}$ & $\begin{array}{l}-0.128 \\
(0.085)\end{array}$ \\
\hline Service workers & $\begin{array}{l}-0.057 \\
(0.070)\end{array}$ & $\begin{array}{l}-0.097 \\
(0.070)\end{array}$ & $\begin{array}{l}-0.033 \\
(0.081)\end{array}$ & $\begin{array}{l}-0.085 \\
(0.082)\end{array}$ \\
\hline Skilled agricultural & $\begin{array}{c}0.057 \\
(0.084)\end{array}$ & $\begin{array}{l}-0.150^{*} \\
(0.085)\end{array}$ & $\begin{array}{c}0.060 \\
(0.097)\end{array}$ & $\begin{array}{l}-0.178^{*} \\
(0.099)\end{array}$ \\
\hline Craft and related trade & $\begin{array}{l}-0.175^{* * *} \\
(0.066)\end{array}$ & $\begin{array}{c}0.035 \\
(0.067)\end{array}$ & $\begin{array}{l}-0.187 * * \\
(0.076)\end{array}$ & $\begin{array}{l}-0.005 \\
(0.078)\end{array}$ \\
\hline Operators and assemblers & $\begin{array}{l}-0.056 \\
(0.149)\end{array}$ & $\begin{array}{l}-0.138 \\
(0.143)\end{array}$ & $\begin{array}{l}-0.057 \\
(0.179)\end{array}$ & $\begin{array}{l}-0.143 \\
(0.171)\end{array}$ \\
\hline Armed forces & $\begin{array}{l}1.196^{* * *} \\
(0.365)\end{array}$ & $\begin{array}{l}1.015 * * * \\
(0.383)\end{array}$ & $\begin{array}{l}1.286^{* * *} \\
(0.423)\end{array}$ & $\begin{array}{l}1.031 * * \\
(0.442)\end{array}$ \\
\hline Unknown & $\begin{array}{l}-0.261 * * * \\
(0.075)\end{array}$ & $\begin{array}{l}-0.101 \\
(0.079)\end{array}$ & $\begin{array}{l}-0.287 * * * \\
(0.087)\end{array}$ & $\begin{array}{l}-0.126 \\
(0.091)\end{array}$ \\
\hline Father's occupation & & & & \\
\hline Managers & $\begin{array}{c}0.090 \\
(0.112)\end{array}$ & $\begin{array}{l}0.319^{* * * *} \\
(0.114)\end{array}$ & $\begin{array}{c}0.076 \\
(0.133)\end{array}$ & $\begin{array}{l}0.429 * * * \\
(0.136)\end{array}$ \\
\hline Professionals & $\begin{array}{l}0.177^{* *} \\
(0.082)\end{array}$ & $\begin{array}{l}0.309 * * * \\
(0.080)\end{array}$ & $\begin{array}{c}0.104 \\
(0.097)\end{array}$ & $\begin{array}{l}0.294 * * * \\
(0.094)\end{array}$ \\
\hline Associate professionals & $\begin{array}{l}-0.283 * * * \\
(0.072)\end{array}$ & $\begin{array}{l}-0.136^{*} \\
(0.073)\end{array}$ & $\begin{array}{l}-0.351^{* * * *} \\
(0.084)\end{array}$ & $\begin{array}{l}-0.116 \\
(0.085)\end{array}$ \\
\hline Clerks & $\begin{array}{l}0.276^{* *} \\
(0.109)\end{array}$ & $\begin{array}{c}0.139 \\
(0.116)\end{array}$ & $\begin{array}{l}0.244^{* *} \\
(0.124)\end{array}$ & $\begin{array}{c}0.139 \\
(0.133)\end{array}$ \\
\hline Service workers & $\begin{array}{l}-0.045 \\
(0.166)\end{array}$ & $\begin{array}{l}-0.223 \\
(0.164)\end{array}$ & $\begin{array}{l}-0.027 \\
(0.195)\end{array}$ & $\begin{array}{l}-0.173 \\
(0.193)\end{array}$ \\
\hline Skilled agricultural & $\begin{array}{l}-0.394 * * * \\
(0.079)\end{array}$ & $\begin{array}{l}-0.085 \\
(0.077)\end{array}$ & $\begin{array}{l}-0.358 * * * \\
(0.092)\end{array}$ & $\begin{array}{l}-0.012 \\
(0.090)\end{array}$ \\
\hline Craft and related trade & $\begin{array}{l}0.209 * * * \\
(0.051)\end{array}$ & $\begin{array}{l}-0.012 \\
(0.053)\end{array}$ & $\begin{array}{l}0.208^{* * * *} \\
(0.060)\end{array}$ & $\begin{array}{l}-0.000 \\
(0.062)\end{array}$ \\
\hline Operators and assemblers & $\begin{array}{l}-0.013 \\
(0.074)\end{array}$ & $\begin{array}{c}0.069 \\
(0.073)\end{array}$ & $\begin{array}{l}-0.043 \\
(0.087)\end{array}$ & $\begin{array}{c}0.036 \\
(0.086)\end{array}$ \\
\hline
\end{tabular}




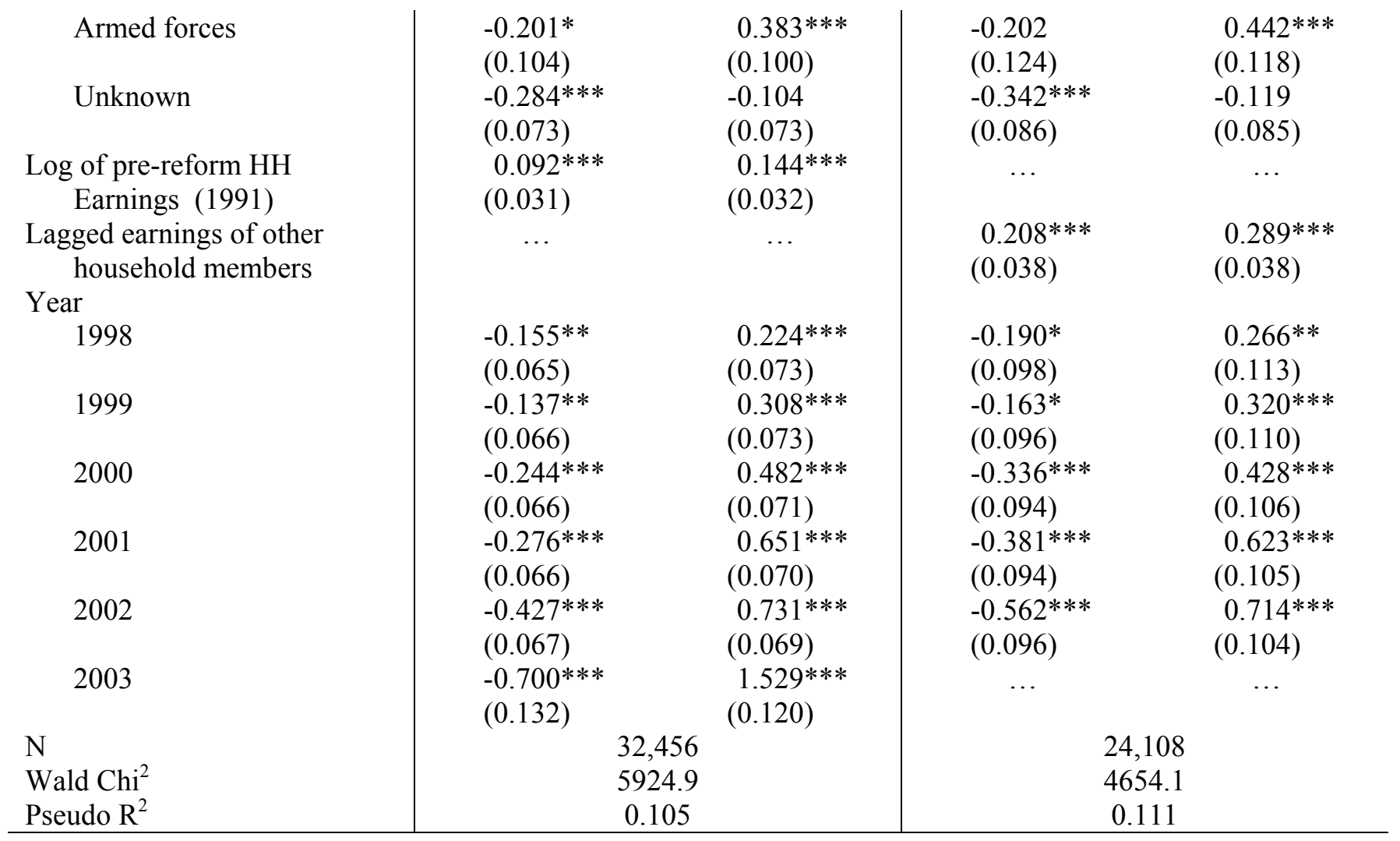

Notes: Working individual is the unit of observation. Robust standard errors are in parentheses; * significant at $10 \%$; ** significant at $5 \% ; * * *$ significant at $1 \%$. Public sector is the base category. The omitted categories are elementary occupations and year 1997. Dummies for regions, pre-reform industry in 1991, missing pre-reform household earnings, and missing lagged income of other household members are included but not shown here. 